\title{
Honor i wstyd, prawo naturalne oraz Pisma. Podstawy Pawłowej argumentacji na temat żeńskich i męskich relacji homoseksualnych w Rz 1,26-27
}

\author{
Honor and Shame, Natural Law, and the Scriptures. The Foundations of Paul's \\ Argumentation on Male and Female Homosexual Relations in Rom 1:26-27
}

\author{
MARCIN KOWALSKI \\ Katolicki Uniwersytet Jana Pawła II w Lublinie \\ xmkowal@kul.pl, ORCID: 0000-0002-8732-6868
}

\begin{abstract}
Streszczenie: Autor analizuje podstawy Pawłowej argumentacji na temat homoseksualizmu w Rz 1,26-27. Po pierwsze są nimi obowiązujące w świecie hellenistycznym kategorie honoru i wstydu, do których apostoł odwołuje się, opisując żeńskie i męskie relacje homoseksualne jako powodowane "haniebnymi namiętnościami” i rozpalonymi „żądzami”, a w konsekwencji prowadzące do "bezwstydu” (Rz 1,26-27). Po drugie Paweł opiera się na prawie naturalnym, które pojmuje nie jako normę kulturową, ale - podobnie jak niektórzy autorzy grecko-rzymscy i żydowscy - jako porządek stworzenia przeniknięty Bożym zamysłem. Po trzecie wreszcie podstawowym punktem odniesienia dla apostoła pozostają Pisma oraz szeroko pojęta tradycja żydowska (Kpł 18,22; 20,13; Pwt 4,16-19; Ps 105,20; Jr 2,11; Mdr 12-15), a zwłaszcza Rdz 1-3 (ze szczególnym naciskiem na Rdz 1,27-28). Wiążą one homoseksualizm z idolatrią, przekraczaniem porządku stworzenia i zacieraniem różnic płciowych między mężczyzną i kobietą. Różnice te służą prokreacji, ale także wzajemnemu zrozumieniu się i uzupełnianiu mężczyzny i kobiety. Zarówno w kwestiach honoru i wstydu, rozumienia natury, jak i powiązania płciowości z prokreacją apostoł może liczyć na sprzymierzeńców dla swojej myśli w postaci autorów grecko-rzymskich i żydowskich, takich jak Platon, Plutarch, Dion Chryzostom, Filon, Józef Flawiusz, Pseudo-Focylides i inni.
\end{abstract}

Słowa kluczowe: Rz 1,26-27, homoseksualizm, honor i wstyd, prawo naturalne, Pisma

Abstract: The author analyzes the foundations of Paul's argument on homosexuality in Rom 1:26-27. First, he points to the categories of honor and shame functioning in the Hellenistic world, which the apostle refers to when he describes male and female homosexual relations moved by "degrading" and "consuming passions," and consequently leading to "shameless acts" (Rom 1:26-27). Second, Paul relies on the natural law, which he perceives not as a cultural norm but, like some Greco-Roman and Jewish authors, as a creation order permeated with God's insight. Third, the primary point of reference for the apostle are the Scriptures and the broadly understood Jewish tradition (Lev 18:22; 20:13; Deut 4:16-19; Ps 105:20; Jer 2:11; Wis 12-15), especially Genesis 1-3 (with particular emphasis on Gen 1:27-28). They connect homosexuality with idolatry, transgressing the order of creation and blurring the distinction between the male and the female. Gender differences serve procreation, but also building up the relationship based on mutual understanding and complementarity between a man and a woman. The apostle finds allies in Plato, Plutarch, Dio Chrysostom, Philo, Flavius Joseph, Pseudo-Phocylides and many others who also refer to the categories of honor and shame, natural law and procreation in their critique of homosexual acts.

Keywords: Romans 1:26-27, homosexuality, honor and shame, natural law, Scriptures 
Pawłowa wypowiedź na temat postaw homoseksualnych, jaką znajdujemy w Rz 1,26-27, uważana jest powszechnie za jeden z najważniejszych tekstów Nowego Testamentu na ten temat. Nic dziwnego zatem, że cieszy się on zainteresowaniem zarówno tych, którzy próbują zdekonstruować krytykę homoseksualizmu u apostoła, jak i tych, którzy bronią jej tradycyjnej interpretacji. Ci pierwsi twierdzą, że Paweł nie potępia $\mathrm{w} \mathrm{Rz} 1,26$ postaw lesbijskich, gdyż nie wiązały się one w starożytności $\mathrm{z}$ wykorzystywaniem drugiego, w przeciwieństwie do męskich relacji homoseksualnych, w których dominowały pederastia i prostytucja ${ }^{1}$. Ich zdaniem takiego właśnie typu związki krytykuje apostoł, nie mając nic przeciwko kochającym się parom homoseksualnym ${ }^{2}$. Paweł nie różniłby się w tym przypadku od innych autorów kultury grecko-rzymskiej, która także odrzucała mężczyzn przyjmujących role pasywnych partnerów, czyniących się podobnymi do kobiet lub sprzedających swoje ciała. Twierdzi się, że w innych przypadkach starożytni nie tylko nie piętnowali homoseksualizmu jako moralnie nagannego, ale nawet byli mu przychylni ${ }^{3}$. W związku z tym, kiedy apostoł pisze w Rz 1,26-27, że żeńskie i męskie kontakty homoseksualne są przeciwne naturze, ma tak naprawdę na myśli starożytne normy kulturowe, którym sprzeciwiają się relacje między kobietami, imitujące role męskie, oraz pasywni homoseksualiści, którzy porzucają swoją męską naturę. Apostoł nie rozumie natury jako uniwersalnego prawa moralnego, bo koncepcja ta w starożytności jeszcze nie funkcjonuje ${ }^{4}$. Wreszcie mówiąc o tradycjach żydowskich, do których odwołuje się Paweł w Rz 1,26-27, stosunkowo mało miejsca poświęca się Rdz 1,27-28 z naciskiem na rozróżnienie płciowe i prokreację. Paweł może iść za tekstami Księgi Mądrości, potępiającymi idolatrię (Mdr 12-15), czy za Kodeksem Świętości (Kpł 18,22 i 20,13), ale nie wtłacza chrześcijan w ramy seksualności prokreacyjnej5.

Powyższe twierdzenia służą dekonstrukcji tradycyjnej interpretacji, według której Paweł odrzuca związki homoseksualne ze względu na prawo natury i wpisane w nie prawo Boże. Pawłowa krytyka, spłaszczona lub ograniczona do aspektu historyczno-kulturowego, prezentuje się jako nieadekwatna i nieaktualna dla współczesnych. Aby dojść do takich wniosków, trzeba jednak dokonać kilku karkołomnych operacji. Pierwszą jest uznanie, że w tradycji grecko-rzymskiej homoseksualizm nie spotykał się z negatywną oceną moralną. Drugą jest zaprzeczenie istnienia choć-

1 Fredrickson, „Natural and Unnatural Use in Romans 1:24-27”, 201; Rogers, Jesus, the Bible, and Homosexuality, 75 .

2 Zob. Bailey, Homosexuality and the Western Christian Tradition, 38, 157; Furnish, The Moral Teaching of Paul, 81; Scroggs, The New Testament and Homosexuality, 116-118, 121-122; Wink, „Homosexuality and the Bible”, 36; Fredrickson, „Natural and Unnatural Use in Romans 1:24-27”, 197-222; Kalin, „Romans 1:26-27 and Homosexuality", 432; Rogers, Jesus, the Bible, and Homosexuality, 74.

3 Taki punkt widzenia prezentuje zasadniczo John Boswell (Christianity, Social Tolerance, and Homosexuality).

4 Boswell, Christianity, Social Tolerance, and Homosexuality, 110-112; Scroggs, The New Testament and Homosexuality, 116-117; MacNeill, The Church and the Homosexual, 52-53; Stegemann, „Paul and the Sexual Mentality of His World”, 164-165; Davies, „New Testament Ethics and Ours”, 315-331. 
by elementarnej koncepcji prawa naturalnego u starożytnych i sprowadzenie go do normy kulturowej. Trzecią wreszcie jest selektywne potraktowanie źródeł myśli Pawła w Rz 1,26-27. Biorąc pod uwagę fakt, jak bardzo rozumienie idei, na których opiera się apostoł, rzutuje na odczytanie jego argumentacji, w artykule tym przyjrzymy się szeroko rozumianej inventio Rz 1,26-27. Rozpoczniemy od kategorii honoru i wstydu, do których odwołuje się tu Paweł, następnie przypatrzymy się jego odniesieniu do natury, kończąc wreszcie Pismami i tradycją żydowską. Pomoże nam to nie tylko lepiej umocować rozumowanie Pawła na temat homoseksualizmu w kulturze grecko-rzymskiej i żydowskiej, ale także odpowiedzieć sobie na pytanie, czy lub do jakiego stopnia apostoł mógł w nich znaleźć sprzymierzeńca w swojej krytyce postaw homoseksualnych.

\section{1. Żeńskie i męskie relacje homoseksualne w starożytnej optyce honoru i wstydu}

W Rz 1,26-27 apostoł dla opisania żeńskich i męskich relacji homoseksualnych odwołuje się do szeregu określeń związanych z kategorią honoru i wstydu. Należą

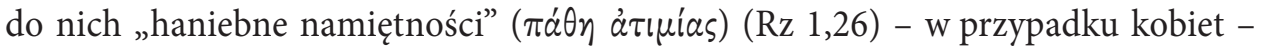

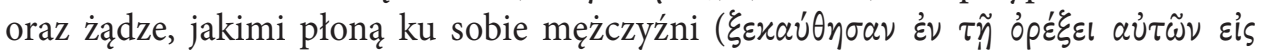

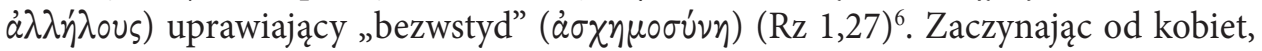
wobec relacji lesbijskich starożytni wykazywali bardzo mało tolerancji, opisując je jako męskie i rozwiązte 7 . Safona z Lesbos, poetka z VI w. przed Chr., model żeńskiego homoseksualizmu, w tym samym stopniu co podziwiana za swój kunszt literacki, była równocześnie krytykowana za rozwiązłość i miłość do kobiet ${ }^{8}$. Wyśmiewali ją autorzy komedii, Horacy nazywał „męską”, zaś najstarsze biografie z III/II w. przed Chr. mówią o jej niemoralności i nieuporządkowanym stylu życia ${ }^{9}$. W tym samym duchu Asklepiades (III w. przed Chr.) wzywa Afrodytę do przeklęcia kobiet, które uprawiają miłość między sobą, gwałcąc przy tym boskie prawa miłości ${ }^{10}$. Dalej Seneka Starszy przytacza fikcyjny przypadek męża, który przyłapawszy swą żonę na aktach $\mathrm{z}$ inną kobietą, zabija obie, będąc absolutnie usprawiedliwiony z powodu mon-

6 Zob. Gagnon, The Bible and Homosexual Practice, 235-239.

7 Na temat relacji lesbijskich w starożytności i odium nad nimi ciążącego zob. Brooten, Love Between Women, 6-7, 29-186 plus str. 9, przyp. 15 i bibliografia (363-372). Zob. także Scroggs, The New Testament and Homosexuality, 140-144; Dover, Greek Homosexuality, 171-184; Miller, „The Practices of Romans 1:26”, 6; Smith, „Ancient Bisexuality and the Interpretation of Romans 1:26-27”, 238-243; Ward, „Why Unnatural?", 263-284; Jewett - Kotansky, Romans, 174; Williams, Roman Homosexuality, 8.

8 Dover, Greek Homosexuality, 173-184; Brooten, Love Between Women, 29-41.

9 Horacy, Ep. 1.19.28 („mascula Sappho”) (referencje do dzieł starożytnych za LCL, chyba, że podano inaczej); Brooten, Love Between Women, 34-35.

10 Brooten, Love Between Women, 42. 
strualności odkrytej zbrodni ${ }^{11}$. Z kolei Owidiusz w swoich Metamorfozach opisuje miłość dwóch młodych kobiet, Ifis i Janty, którą ta pierwsza nazywa niesłychaną, monstrualną, nienaturalną, niezgodną z wolą bogów i zwyczajem. Dramat zostaje rozwiązany w chwili, kiedy Izyda przemieni Ifis w chłopca, umożliwiając jej małżeństwo z Jantą ${ }^{12}$.

Być może, czyniąc aluzję do relacji typu lesbijskiego, Seneka Młodszy pisze o kobietach swoich czasów, które bezwstydnie przejęły męskie zachowania, rywalizując z mężczyznami w pożądaniu, podobnie jak oni przesiadując do późna w nocy, jedząc i pijąc ${ }^{13}$. Marcjalis z kolei wzmiankuje wprost dwie kobiety - Filenis, która słynęła $\mathrm{z}$ agresywnego zachowania zarówno wobec mężczyzn, jak i kobiet, żyła jak mężczyzna i uprawiała sporty atletyczne, oraz Bassę, która oddawała się miłości do kobiet, w swoim pożądaniu naśladując mężczyzn ${ }^{14}$. W pierwszym opisie wyraźnie daje o sobie znać hiperbolizacja męskości Filenis, wyszydzona przez autora, w drugim zaś fałsz i odraza związane z odkryciem, że cnotliwa - wydawało się - kobieta, która stroni od mężczyzn, w istocie oddaje się nienasyconemu pożądaniu $z$ kobietami. Lukian z Samosaty (II w.) w podobny sposób pisze o kobietach z Lesbos o męskim wyglądzie, które łączyły się tylko z kobietami, jakby same były mężczyznami. Jedną z nich była bogata Megilla, która kazała nazywać się Megillosem, nie chciała być określana jako kobieta, miała za żonę Demonassę i posiadała, jak twierdziła, umysł i pragnienia mężczyzny, w niczym mu nie ustępując. Laena, którą ją poznała, była zawstydzona samym opowiadaniem o tym ${ }^{15}$. Wspólnym mianownikiem tych opisów jest wstyd, jaki akty typu lesbijskiego sprowadzają na kobiety, i odraza, jaką budzą one u odbiorców ${ }^{16}$. Autorzy nie podają uzasadnienia dla bezwstydności tego typu zachowania, ponieważ wydaje się być ono zrozumiałe dla ich czytelników.

Najbardziej wyczerpujący opis reakcji starożytnych na związki lesbijskie można znaleźć w książce Bernadette Brooten Love between Women, analizującej zaklęcia magiczne, teksty astrologiczne i medyczne oraz klasyfikacje snów, w których pojawiają się wątki miłości między kobietami ${ }^{17}$. Tylko pierwsza kategoria to literatura tworzona przez kobiety lub na ich zapotrzebowanie, pozostałe zaś przedstawiają negatywne spojrzenie na relacje lesbijskie artykułowane przez mężczyzn, którzy postrzegali je jako wyuzdane i nienaturalne. Niechęć wobec żeńskiego homoseksualizmu wynikała według autorki z zagrożenia, jakie stwarzał on dla tradycyjnego obrazu kobiety podporządkowanej mężczyźnie, której największymi cnotami miały być czystość

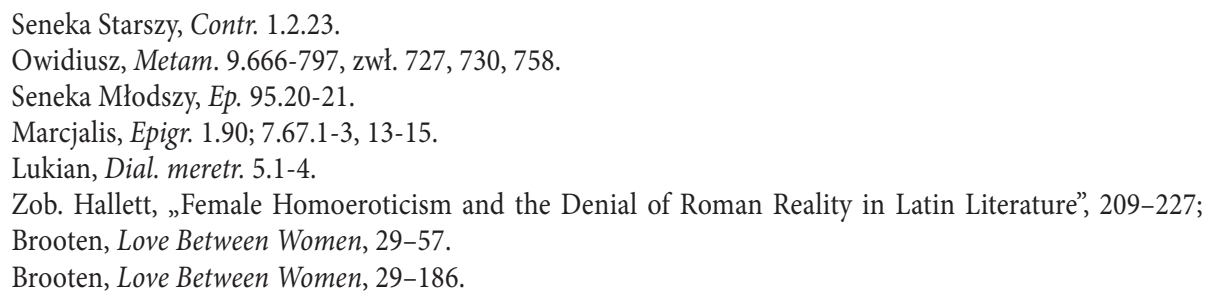


i wierność, odbijające się w jej roli żony i matki ${ }^{18}$. Biorąc pod uwagę fakt, że w wysoce zhierarchizowanym społeczeństwie patriarchalnym honor kobiety odbijał się na honorze mężczyzny, w interesie mężczyzn leżało napiętnowanie przejmujących ich role, wyemancypowanych kobiet. W ich zachowaniu starożytni dostrzegali jednak coś więcej niż tylko wykroczenie przeciw powszechnie obowiązującemu porządkowi

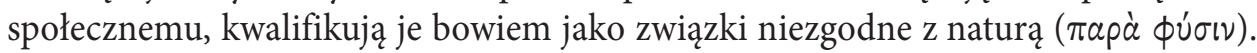
O ile w opisach snów Artemidorusa, które analizują Brooten i John J. Winkler, natura pokrywa się w pewien sposób z kulturą, o tyle nie można tego powiedzieć o tekstach astronomicznych i medycznych, do czego jeszcze powrócimy ${ }^{19}$.

Pozostając wciąż przy kategoriach honoru i wstydu, Paweł opisuje relacje mię-

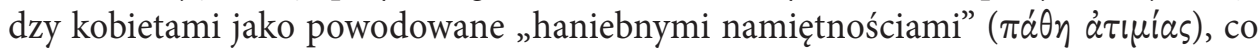
odpowiada opisom Filenis i Bassy u Marcjalisa, czy Megilli u Lukiana z Samosaty. Żądza i pożądanie przebija także z opisów żeńskiego homoseksualizmu w tekstach astronomicznych i medycznych Vettiusa Valensa, Hermesa Trismegistosa, Firmicusa Maternusa czy Soranosa ${ }^{20}$. Co ciekawe Firmicus Maternus, podobnie jak Paweł, zestawia „nieczyste żądze” kobiet z tymi, które wykazują mężczyźni, godzący się na pasywną rolę w związkach homoseksualnych (cinaedi) ${ }^{21}$. Apostoł, nie rozróżniając między postawami pasywnymi bądź aktywnymi, podobnie ilustruje żeński i męski homoseksualizm, przedstawiając mężczyzn w Rz 1,27 jako pałających ku sobie po-

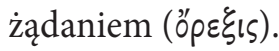

Według stoików őp $\varepsilon_{\xi}$ is to pragnienie prowadzące do osiągnięcia tego, co dobre, tymczasem rozpalone - prowadzi do frustracji i wynaturzeń, objawiających się w relacjach homoseksualnych ${ }^{22}$. Męskie związki tego typu regularnie pojawiają się w towarzystwie takich wad, jak: rozpusta, zepsucie, nadmierne pragnienie wygód i przyjemności, pijaństwo czy niepohamowany apetyt. Dion Chryzostom wiąże je z żądzą i uzależnieniem. Według autora to prostytucja przygotowuje grunt do wykorzystywania kobiet i chłopców z dobrych rodzin, prowadzi do rozbudzenia pożądań, które przekraczają granice ustanowione przez naturę, a w konsekwencji do relacji homoseksualnych ${ }^{23}$. Mężczyźni poszukujący w ten sposób chłopców przypominają tych uzależnionych od alkoholu, którzy wytwarzają w sobie silne pragnienie wciąż nowych doznań ${ }^{4}$. Filon w opisie Sodomy łączy homoseksualizm z nieprawością, pijaństwem, obżarstwem, rozwiązłością, niepohamowaniem oraz nadmiarem

18 Brooten, Love Between Women, 359-362 oraz 18-20, przyp. 38 na temat innych autorów podejmujących kwestię relacji lesbijskich, kwestionujących porządek społeczny. Bernadette Brooten dotrzega także w Rz 1,26 strategię Pawła, podporządkowującego kobiety mężczyznom.

19 Na temat snów zob. Winkler, The Constraints of Desire, 17-44; Brooten, Love Between Women, 175-186.

20 Brooten, Love Between Women, 130-132, 137, 150, 155.

21 Brooten, Love Between Women, 137.

22 Inwood, Ethics and Human Action in Early Stoicism, 114-115, 223-241; Fredrickson, „Natural and Unnatural Use in Romans 1:24-27", 213-215.

23 Dion Chryzostom, Or. 7.133-139.

24 Dion Chryzostom, Or. 7.149-152. 
dóbr. Obfitość, w jaką opływali mieszkańcy Sodomy i z jakiej korzystali bez umia$\mathrm{ru}$, doprowadziła ich ostatecznie do niepohamowanego apetytu seksualnego także wobec mężczyzn ${ }^{25}$. Podobne powiązanie postaw homoseksualnych $\mathrm{z}$ arogancją, brakiem pobożności i prostytucją widać w Wyroczniach Sybillińskich (3.184-190), gdzie znajdujemy opis mężczyzn oddających się mężczyznom i wystawiających chłopców w domach publicznych, czemu towarzyszy wykorzystywanie innych, miłość zysku i niegodziwego bogactwa. W Liście Arysteasza (152) relacje między mężczyznami połączone są z kolei w jedno $\mathrm{z}$ relacjami kazirodczymi, będącymi synonimem pogaństwa, którego Izrael nie naśladuje.

Obrazy łączące homoseksualizm z innymi występkami, szczególnie brakiem samoopanowania i żądzą, uderzają w honor mężczyzny, ponieważ do jego cnót kardynalnych należy zdolność do samoopanowania oraz kierowanie się najszlachetniejszą częścią duszy, czyli rozumem ${ }^{26}$. Od mężczyzny wymaga się panowania nad swoimi pasjami, takimi jak gniew, chciwość, pożądanie czy przyjemność. Panowanie takie jest atrybutem męskości i usprawiedliwia władzę mężczyzny nad kobietą oraz całym domostwem ${ }^{27}$. Pożądanie ( $\pi \dot{\theta} \theta 0 \varsigma$ ) Platon nazywał tyranicznym panem (Resp. 575A-C), zaś stoicy diagnozowali jako sprzeczne $\mathrm{z}$ rozumem i określali jako chorobę duszy ${ }^{28}$. W przypadku relacji homoseksualnych rozum zostaje zupełnie zaciemniony przez pasje, co oznacza brak cnoty i animalistyczną wręcz seksualność ${ }^{29}$.

Starożytni uznawali stosunki między przedstawicielami tej samej płci za poniżające szczególnie dla mężczyzny, który poddawał się im na sposób pasywny, tracąc w ten sposób swoją męskość (andreia). Pasywność ta sprawiała, że stawał się on podobnym do kobiety i brakowało mu cnót, takich jak odwaga. Platon stwierdza wprost, że nikt nie wierzy, aby związki homoseksualne, w których pasywni partnerzy oskarżani są o tchórzostwo i grają rolę kobiet, promowały cnotę $e^{30}$. Plutarch nazywa pasywnych męskich partnerów afrontem dla Afrodyty ${ }^{31}$. Według Filona tacy mężczyźni okazują brak szacunku dla własnej natury, przywykli do bycia traktowanymi

Filon, Abr. 133-134.

Na temat argumentacji w Rz 1,27, uderzającej w honor mężczyzn uprawiających stosunki homoseksualne, zob. Dunn, Romans, 74; Jewett - Kotansky, Romans, 179.

O tym, że mężczyzna powinien być wzorem cnót, jako głowa i przewodnik dla kobiety, zob. m.in. w: Osiek -Balch, Families in the New Testament World, 56-57; Osiek - Pouya, „Constructions of Gender in the Roman Imperial World", 45-46. Na temat braku kontroli nad swoimi pożądaniami i braku męskości zob. Williams, Roman Homosexuality, 151-156.

Na temat negatywnych pasji, ich typologii i natury u stoików, zob. SVF 3.377-420, 456-490. O potrzebie ich wykorzenienia, zob. SVF 3.443-455. Teksty SVF (Stoicorum Vetera Fragmenta) za Arnim - Radi-

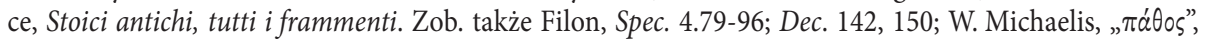
TDNT V, 926-927; Jewett - Kotansky, Romans, 172-173. Fredrickson („Natural and Unnatural Use in Romans 1:24-27”, 209-211) słusznie argumentuje za seksualnymi konotacjami pathe w Rz 1,26. Więcej na temat teorii pathe zob. w: Inwood, Ethics and Human Action in Early Stoicism, 154-173.

Wilckens, Der Brief an die Römer, I, 110.

Platon, Leg. 836D-E.

Plutarch, Amat.751D-E. 
jak kobiety, cierpią na chorobę zniewieściałości, upodlenie dusz i stają się przyczyną zepsucia rasy ludzkiej ${ }^{32}$. Filon pisze o uprawiających pederastię chłopcach zmieniających się w kobiety, będących hańbą dla siebie, dla swojego domu i kraju oraz całej ludzkości ${ }^{33}$. Potępia jednak także aktywnych partnerów, którzy zamiast uczyć młodych męstwa, uczą ich zniewieściałych żądzy i pozbawiają męskości ${ }^{34}$. Relacje homoseksualne autor nazywa ostatecznie wulgarnymi i rozwiązłymi, odbierającymi odwagę i okradającymi mężczyznę z jego wartości. Psują one dusze, ciała i charaktery młodych oraz zaciemniają ich umysły pożądaniem ${ }^{35}$.

Amy Richlin w swoim artykule dobrze dokumentuje brak akceptacji w kulturze grecko-rzymskiej dla dorosłych, wolnych mężczyzn, którzy ciesząc się prawami obywatelskimi, pozwalali się penetrować innym mężczyznom ${ }^{36}$. Większym przyzwoleniem cieszyły się relacje dorosłych mężczyzn z chłopcami (puer) - pederastia - występujące zarówno wśród Greków, jak i Rzymian ${ }^{37}$. Związki mężczyzn z chłopcami w wieku dojrzewania (nastolatkowie między okresem dziecięcym i młodzieńczym) w Grecji łączyły się z gimnazjonem i instytucją starszego tutora, który angażując się w relację z młodszym, stawał się równocześnie jego nauczycielem. Rzymianie nie byli jednak entuzjastami tego rodzaju wychowania, które według niektórych autorów prowadziło do zepsucia i rozwiązłości, ale przede wszystkim godziło w status i honor wolnych mężczyzn ${ }^{38}$. Do arsenału publicznych, karalnych i odbierających honor oskarżeń należało stwierdzenie, że ktoś uwiódł wolnego chłopca z dobrej rodziny lub sam jako młodzieniec poddawał się pasywnym relacjom homoseksu$a \operatorname{lnym}^{39}$. Sam Cezar musiał mierzyć się z prześmiewczymi komentarzami na temat relacji młodzieńczych z Nikomedesem, królem Bitynii. Dolabella nazywał go „rywalem królowej”, jego partner w konsulacie „królową Bitynii”, a właśni żołnierze śpiewali: „Cezar zdobył Galię, a Nikomedes Cezara” ${ }^{40}$. W podobny sposób August był

32 Filon, Abr. 135-136.

33 Filon, Spec. 3.37-38.

34 Filon, Spec. 3.39.

35 Filon, Contempl. 60. Na te tematów zacierania ról płciowych i niepohamowania w pasji u Filona, ale także innych autorów grecko-rzymskich i żydowskich, zob. Gagnon, The Bible and Homosexual Practice, 169-178.

36 Richlin, „Not Before Homosexuality”, 523-573. Zob. także Williams, Roman Homosexuality, xiii-xiv, 17-19, 145-148.

37 Richlin, „Not Before Homosexuality”, 533-534; Williams, Roman Homosexuality, 67-84, 203-208, ten drugi fragment na temat większej akceptacji dla relacji z chłopcami niż z dorosłymi mężczyznami (cinaedi). Na temat bogatej kolekcji tekstów źródłowych, traktujących kwestię homoseksualizmu w Grecji i w Rzymie, zob. Hubbard, Homosexuality in Greece and Rome.

38 Zob. Pliniusz Młodszy, Ep. 3.3.4-5; 7.24.3; Cyceron, Cael. 6-15. Zob. także MacMullen, „Roman Attitudes to Greek Love”, 494-495; Richlin, „Not Before Homosexuality”, 537-538, 546; Williams, Roman Homosexuality, xiv, 14, 74-76. Także Boswell (Christianity, Social Tolerance, and Homosexuality, 80-81) zwraca uwagę na dzieci wolnych obywateli chronione przed wykorzystywaniem w relacjach homoseksualnych.

39 Richlin, „Not Before Homosexuality”, 531-532, 537-539.

40 Swetoniusz, Jul. 49. 
wyśmiewany za bycie puer dla Cezara i innych ${ }^{41}$. Niektórzy, upubliczniając relacje $\mathrm{z}$ młodymi chłopcami $\mathrm{z}$ dobrych rodzin $\mathrm{w}$ sądzie, uderzali w ten sposób w honor ich ojców ${ }^{42}$. Z tym większą niechęcią spoglądano na współżyjących ze sobą dorosłych wolnych mężczyzn ${ }^{43}$.

Rzymskie zwyczaje wykluczały i piętnowały relacje seksualne między wolnymi obywatelami jako szkodliwe. Uprawianie ich na sposób pasywny w wieku męskim wiązało się z utratą publicznego honoru i byciem nazywanym cinaedus - chorym, delikatnym, słabym, nieczystym czy rozwiązłym ${ }^{44}$. W Rzymie istniały także regulacje prawne i cywilne ograniczające prawa i pozbawiające urzędów obywateli występujących w roli pasywnych kochanków, uprawiających seks z wolnymi mężczyznami i chłopcami lub prostytuujących się $e^{45}$. Nakładana wówczas infamia wykluczała ze stanu senatorów czy ekwitów, pozbawiała praw obywatelskich i pozycji społecznej oraz ściągała publiczny dyshonor. Zachowania takie regulowano głównie przez zwyczaj, instytucje rodzinne (paterfamilias) i społeczne, ale penalizowały je także edykty pretorskie i niektóre prawa, jak lex Scantinia czy późniejsze lex Julia municipalis oraz lex Julia de adulteriis coercendis ${ }^{46}$. Na temat penalizacji aktów homoseksualnych związanych z prostytucją i pederastią, w których uczestniczyli wolni obywatele, utraty statusu i przyszłych urzędów, a nawet kary śmierci w antycznej Grecji pisze także Kenneth J. Dover ${ }^{47}$. Chociaż autorzy tacy jak Richlin czy Craig A. Williams argumentują za skomplikowanym obrazem stosunku starożytnych do męskiego homoseksualizmu (ganiony i piętnowany, a równocześnie tolerowany i znajdujący przychylność $\mathrm{w}$ literaturze i sztuce), zgromadzone przez nich argumenty przemawiają za brakiem sympatii dla relacji homoseksualnych praktykowanych między wolnymi obywatelami w starożytnej kulturze rzymskiej. Williams wskazuje na ich akceptowalność pod warunkiem, że nie dotyczyły one wolnych mężczyzn i wyraźnie odbijały status oraz asymetryczne relacje siły i podległości ${ }^{48}$.

Ramsey MacMullen w swoim dobrze udokumentowanym artykule „Roman Attitudes to Greek Love” idzie jeszcze dalej, stwierdzając zasadniczy brak akceptacji dla wszelkiego homoseksualizmu w starożytnym rzymskim społeczeństwie. Zjawisko to kojarzone według niego z zepsuciem Greków (more Graeciae) ${ }^{49}$, bogactwem

\footnotetext{
41 Zob. Swetoniusz, Aug. 68, 71.1. Na temat podobnych relacji o Domicjanie zob. Swetoniusz, Dom. 1.1.

42 Zob. Tacyt, Ann. 11.2.

43 Richlin, „Not Before Homosexuality”, 539-540.

44 Richlin, „Not Before Homosexuality”, 530-531, 533-534; Williams, Roman Homosexuality, 191-200.

45 Richlin, „Not Before Homosexuality”, 530, 554-571; Williams, Roman Homosexuality, 208-216.

46 Bailey, Homosexuality and the Western Christian Tradition, 65-67; Richlin, „Not Before Homosexuality”, 558-571; DeYoung, „The Meaning of 'Nature' in Romans 1”, 436. Na temat sprzeciwu wobec jakiejkolwiek penalizacji homoseksualizmu w Rzymie zob. Boswell, Christianity, Social Tolerance, and Homosexuality, 65-71.

47 Dover, Greek Homosexuality, 19-39.

48 Williams, Roman Homosexuality, xiv, 17-19, 31-50, 145-148.

49 Cyceron, Tusc. 5.58.
} 
i wyższymi, miejskimi sferami, pozostawało bez sympatii u większości. Autor opiera swoje wnioski m.in. na mowach Cycerona, w których relacje homoseksualne nazywane są sprośnymi i zepsutymi, kojarzone $\mathrm{z}$ wadami i brakiem powściągliwości, co byłoby absolutnie niezrozumiałe i nieskuteczne, gdyby nie przemawiało do zbiorowego osądu większości ${ }^{50}$. Nie tylko pasywne, ale wszelkiego rodzaju akty homoseksualne, także te podejmowane z niewolnikami, dla starożytnych byłyby moralnie godne potępienia. Etyczna neutralność tego typu zachowań jest według MacMullena mało prawdopodobna, biorąc także pod uwagę fakt, jak pikantne są zawierające odniesienia do nich mowy; chodzi o tematy gorące, budzące uczucia potępienia i wstydu ${ }^{51}$. Istnieje co prawda cała rzesza autorów, którzy otwarcie przyznają się do homoseksualizmu i afirmują go w swoich dziełach, jak Katullus, Tibullus, Persjusz, Marcjalis czy Juwenalis. Spośród imperatorów Domicjan, Neron i wielu innych znanych było z preferencji homo- lub biseksualnych ${ }^{52}$. Fakt, że opisuje się ich czyny, nie oznacza jednak tolerancji dla nich, o czym może świadczyć choćby stosunek Rzymian do Nerona ${ }^{53}$. Ostatecznie według MacMullena osąd większości społeczeństwa był krytyczny wobec relacji homoseksualnych, kojarzonych z urbanitas, zepsuciem właściwym dla bogatych elit miejskich ${ }^{54}$. Wymownym dowodem na to jest głos zwykłego obywatela, oskarżającego bogatych, którzy mają swoje zabawki w postaci chłopców - niewolników, odgrywających dla nich role kobiet. Znakomita większość społeczeństwa, według mówcy, żeni się i zakłada rodziny, polegając na nich w czasie życiowych trudności ${ }^{55}$.

Argumentacja MacMullana i Richlin staje tu w wyraźnej opozycji wobec Johna Boswella, który w swoim wpływowym studium na temat homoseksualizmu w świecie antycznym Christianity, Social Tolerance and Homosexuality, optuje za sympatią dla tego zjawiska w kulturze grecko-rzymskiej. Według niego starożytny homoseksualizm, poza rzadkimi i mało znaczącymi przypadkami nietolerancji, nie był uważany za szkodliwy, dziwny, niemoralny czy zagrażający rzymskim obyczajom, będąc dobrze zintegrowanym z ówczesnym życiem społecznym i kulturą ${ }^{56}$. Autor próbuje także dowieść braku penalizacji dla relacji homoseksualnych, zwiększającej się tolerancji dla nich w początkowym okresie Imperium Romanum, ich powszechności, legalnego charakteru (ceremonie przypominały heteroseksualne małżeństwa), a nawet

50 MacMullen, „Roman Attitudes to Greek Love”, 490-491. Autor przytacza mowy Cycerona przeciw Pizonowi, Klodiuszowi, Gabiniuszowi, Werresowi, Katylinie czy Markowi Antoniuszowi, przedstawianym jako uzależnionym od relacji homoseksualnych.

51 MacMullen, „Roman Attitudes to Greek Love”, 492.

52 Na temat relacji między mężczyznami, różnych od pederastii, zob. także Smith, „Ancient Bisexuality and the Interpretation of Romans 1:26-27", 234-237; Williams, Roman Homosexuality, 84-93.

53 MacMullen, ,Roman Attitudes to Greek Love”, 495-496.

54 MacMullen, „Roman Attitudes to Greek Love”, 497-498.

55 [Kwintylian], Decl. 337.14-16; MacMullen, „Roman Attitudes to Greek Love”, 498.

56 Boswell, Christianity, Social Tolerance, and Homosexuality, 87. 
ich stałości (związki na całe życie) ${ }^{57}$. Twierdzi też, powołując się na popularność prostytuujących się mężczyzn odgrywających rolę aktywną (exoleti), że z biegiem czasu podział na pasywnych i aktywnych partnerów przestał w rzymskim społeczeństwie odgrywać znaczącą rolę ${ }^{58}$.

Richlin kwalifikuje to bogate w odniesienia historyczne opracowanie jako posiadające nachylenie "aktywistyczne”, co znajduje swoje odzwierciedlenie w wybiórczym traktowaniu źródeł i jednostronnym argumentowaniu za sympatią dla homoseksualizmu w kulturze antycznej oraz co najmniej obojętnym stosunku doń w Biblii. Boswell, mówiąc o akceptacji dla stosunków homoseksualnych w Rzymie, przytacza głównie przykłady dotyczące pederastii, niewolników i prostytucji, pomija zaś w znacznym stopniu lub lekceważy sytuację społeczną dorosłych obywateli praktykujących pasywne relacje homoseksualne (cinaedi) ${ }^{59}$. Właśnie cinaedi odpowiadają współczesnym relacjom homoseksualnym, dla których - według MacMulena oraz Richlin - starożytni nie mieli sympatii, uznając je za zepsute i penalizując $^{60}$. Także Dover, a za nim David M. Halperin i Winkler, rozróżniają pomiędzy aktywnym i pasywnym homoseksualizmem, argumentując za brakiem społecznej akceptacji dla mężczyzn, którzy pozwalali wykorzystywać swoje ciała do penetracji przez innych ${ }^{61}$. Sam Boswell, wbrew optymistycznemu obrazowi relacji homoseksualnych, stwierdza zresztą, że wolni obywatele chronili przed nimi swoje dzieci6 ${ }^{62}$. Ostatecznie autor wyprowadza swoje wnioski o akceptacji dla homoseksualizmu z materiału opisującego życie imperatorów (nie będących najlepszym wzorem moralności) oraz literatury będącej produktem wykształconych elit miejskich (także charakteryzujących się większym permisywizmem moralnym). $Z$ drugiej strony lekceważy on pojawiające się w literaturze pejoratywne powiązanie między relacjami homoseksualnymi, rozwiązłością a miłością do zbytku. To stawia pod znakiem zapytaniem historyczną wiarygodność jego sądów na temat sympatii dla homoseksualizmu w świecie antycznym.

Niechęć do tego typu zachowań wynikała także z powiązania między kwestiami honoru i wstydu a płciowością i moralnością. Boswell, Halperin, Winkler oraz Williams twierdzą, że w podejściu starożytnych płeć nie odgrywała takiej roli jak status społeczny, a sposobom uprawiania seksu nie nadawano znaczenia moralne-

57 Boswell, Christianity, Social Tolerance, and Homosexuality, 61-87.

58 Boswell, Christianity, Social Tolerance, and Homosexuality, 79 oraz 81-82.

59 Richlin, „Not Before Homosexuality”, 528-529.

60 Prócz wspomnianego już artykułu Amy Richlin, zob. także MacMullen, „Roman Attitudes to Greek Love”, 484-502.

61 Dover, Greek Homosexuality, 100-109; Halperin, One Hundred Years of Homosexuality, 22-24, 30-38, 47-48, 97, 130-134; Winkler, The Constraints of Desire, 45-70.

62 Boswell (Christianity, Social Tolerance, and Homosexuality, 74-75) wspomina także uprzedzenia wobec cinaedi i wolnych młodych obywateli, którzy angażowali się w stosunki homoseksualne, ale nie zmienia to jego zdania co do ogólnej tolerancji według tego typu zachowań. 
go ${ }^{63}$. Richlin nie zgadza się z tym, przytaczając przypadki oskarżeń i osądów moralnych, którym podlegało życie cinaedi w starożytności ${ }^{64}$. Do nich dołączyć możemy także negatywne oceny, jakie na temat relacji homoseksualnych w ogólności wydają wspomniani już Platon, Plutarch, Dion Chryzostom, Filon oraz inni autorzy żydowscy. Powiązanie homoseksualizmu $\mathrm{z}$ wadami oraz zagrożenie dla cnót, jakie stwarzał on nie tylko dla pasywnych partnerów, każe widzieć w nim zjawisko o charakterze zarówno kulturowym, jak i moralnym. Seksualności nie da się tu odłączyć od moralności, podobnie jak nie da się całkowicie odłączyć starożytnego homoseksualizmu od jego współczesnych wersji. Dover, Halperin i Winkler powtarzają za Michelem Foucaultem, że nie istnieje korespondencja pomiędzy starożytnym a nowożytnym ujęciem homoseksualizmu, który w sensie pojęciowym jest konstruktem XIX-wiecznym, zaś jako zjawisko dotyka naszych czasów ${ }^{65}$. Richlin takie powiązanie widzi w cinaedi, mężczyznach, którzy z własnej woli oddawali się pasywnym relacjom homoseksualnym ${ }^{66}$. Jako aktywistyczne autorka określa także pozycje Halperina i Winklera, którzy starają się wyrwać seksualność z oków nałożonych nań przez naznaczoną duchem chrześcijańskim kulturę i uznają tożsamość płciową za konstrukt kulturowy.

Podsumowując, Paweł, opisując relacje lesbijskie jako rozwiązłe i hańbiące, znajduje zdecydowanego sprzymierzeńca w kulturze grecko-rzymskiej. Apostoł za podobnie odbierający honor i degradujący uważa męski homoseksualizm. W świecie starożytnym cieszył się on większym przyzwoleniem, z którego jednak wykluczano wolnych obywateli, przyjmujących w relacjach z innymi mężczyznami poniżającą, podporządkowaną, właściwą kobietom rolę (cinaedi). Paweł nie czyni żadnej różnicy pomiędzy dominującymi a podporządkowującymi się partnerami męskimi, używając bardzo ogólnego języka, krytykującego wszelkie tego typu relacje. Opisuje mężczyzn angażujących się w nie jako płonących żądzą i nie potrafiących nad sobą zapanować. Pod względem hańbiących żądz przypominają oni oddające się sobie kobiety. Zarówno żeński, jak i męski homoseksualizm uderzają w honor uprawiających go, z czym zasadniczo zgodziliby się grecko-rzymscy odbiorcy Rz 1,18-32. Mogliby oni ewentualnie oponować przeciw potępieniu przez apostoła wszelkich relacji między mężczyznami, choć przyjmując argumentację MacMullena, opozycja ta dotyczyłaby jedynie nieznacznej mniejszości elit miejskich. Paweł w swojej krytyce homoseksualizmu może liczyć na zrozumienie większości grecko-rzymskich adresatów. Katego-

63 Richlin, „Not Before Homosexuality”, 526-528. Zob. także Boswell, Christianity, Social Tolerance, and Homosexuality, 72-73, 87; Halperin, One Hundred Years of Homosexuality, 22-23, 68-69, 95; Winkler, The Constraints of Desire, 11, 46, 50, 59 .

64 Richlin, „Not Before Homosexuality”, 528, 530. Zob. także Cohen, Law, Sexuality and Society; Cohen, „Sexuality, Violence, and the Athenian Law of Hubris”, 171-188.

65 Winkler, The Constraints of Desire, 4; Halperin, One Hundred Years of Homosexuality, 8, 18, 24; Boyarin, „Are There Any Jews in 'the History of Sexuality'?", 353.

66

Richlin, „Not Before Homosexuality”, 526. 
rie honoru i wstydu nie są jednak jedynymi, na których się opiera, określając związki homoseksualne także jako „przeciwne naturze”.

\section{Prawo naturalne i pojęcie natury $w$ argumentacji na temat żeńskich i męskich związków homoseksualnych}

Ważną podstawę dla krytyki wszelkiego rodzaju związków natury homoseksualnej Paweł znajduje w koncepcji prawa naturalnego, do którego elementów nawiązuje w Rz 1,26-27. Apostoł stwierdza, że relacje między kobietami są sprzeczne z natu-

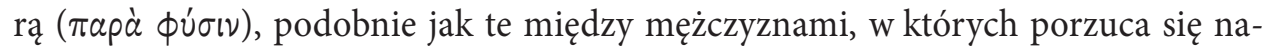

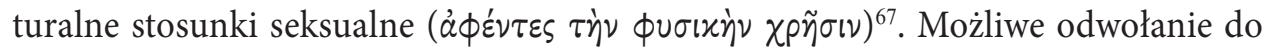
prawa naturalnego, które znajdujemy w Rz 1,26-27, kwestionuje się dziś na wiele sposobów. Boswell twierdzi, że samo pojęcie prawa naturalnego nie istniało w starożytności, powstało $\mathrm{w}$ średniowieczu i anachronizmem byłoby poszukiwać odniesień do niego u Pawła ${ }^{68}$. Winkler $z$ kolei argumentuje za naturą, która w tekstach o relacjach homoseksualnych powinna być utożsamiana z kulturą, wychodząc od prostego faktu: seksualność i jej rozumienie są uwarunkowane kulturowo, podlegają ewolucji i mogą być badane jak każde inne zjawisko kulturowe ${ }^{69}$. Paweł byłby zatem przeciwnikiem relacji między kobietami, bo te w sposób oczywisty kwestionują porządek społeczeństwa patriarchalnego, o czym wspomnieliśmy już powyżej. Byłby też przeciwny związkom między wolnymi mężczyznami, w których ci ostatni przyjmują pasywną rolę, właściwą kobietom. W obu przypadkach apostoł, krytykując „nienaturalność", broniłby zasadniczo norm kulturowych właściwych starożytnemu społeczeństwu, wyraźnie rozróżniającemu między pasywną - żeńską i aktywną - męską rolą płciową.

Taka interpretacja argumentacji apostoła w Rz 1,26-27 jest tylko częściowo uzasadniona i posiada sporo słabych punktów. Po pierwsze, ogranicza ona Pawłową krytykę jedynie do mężczyzn przyjmujących pasywną rolę w związkach homoseksualnych, czego śladu nie ma u Pawła. Po drugie, releguje koncepcję prawa naturalnego do czasów znacznie późniejszych, przeoczając fakt, że jej elementy pojawiają się już w starożytności, na przykład u Cycerona (lex naturae $)^{70}$. Po trzecie wreszcie, sprowadzenie seksualności i płciowości jedynie do normy kulturowej nie zgadza się z ich rozumieniem u starożytnych. Kiedy Paweł mówi o relacjach homoseksualnych jako

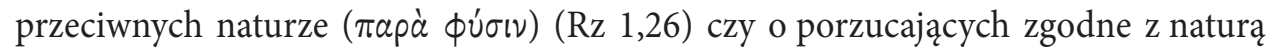

67 Na temat słowa $\chi \rho \tilde{\eta} \sigma i \zeta$, które oznacza także stosunek seksualny, zob. Fredrickson, „Natural and Unnatural Use in Romans 1:24-27", 199-207; Gagnon, The Bible and Homosexual Practice, 236-237.

68 Boswell, Christianity, Social Tolerance, and Homosexuality, 110.

69 Winkler, The Constraints of Desire, 17-18, zob. także szerzej 17-43.

70 Cyceron, Off. 3.6.27. 


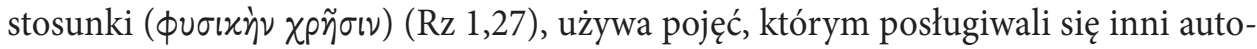
rzy jego czasów, opisując $w$ ten sposób relacje homoseksualne ${ }^{71}$. Ich traktowanie tej kwestii wykracza poza zwyczaj czy normę kulturową, wiążąc się z boskimi, określającymi naturę człowieka prawami.

Dobrym przykładem jest Platon, który w swoich Prawach pisze o naturalnym

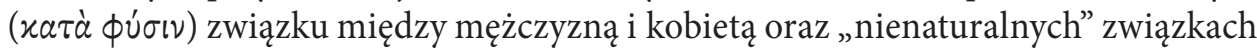
homoseksualnych ( $\pi a \rho \dot{\alpha} \phi u ́ \sigma เ v)$, które powodowane są brakiem samokontroli w odniesieniu do przyjemności (Leg. 636C). Źródło przyjemności, według autora, bije w naturze, a szczęśliwe życie polega na właściwym korzystaniu z niej (Leg. 636D).

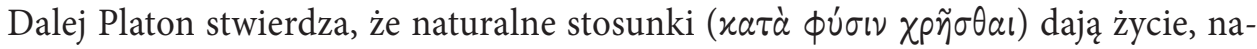
leży zatem powtrzymać się od prostytucji i stosunków między mężczyznami, tak jak nie sieje się na skałach i kamieniach. Takie prawo idzie za wskazaniami natury

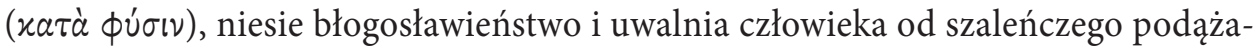
nia za przyjemnością (Leg. 838E-839A). Według Platona stanem idealnym byłoby, gdyby prostytucja oraz wszelkiego rodzaju związki homoseksualne były zabronione, a seks służył prokreacji (Leg. 841D). Autor ma świadomość, dając temu wyraz $\mathrm{w}$ tekście, że prawo takie byłoby trudne do przestrzegania i zbyt idealistyczne, dla nas jednak istotne jest, że wiąże ono pojęcie natury z seksualnością i funkcją przekazywania życia oraz cnotą. Roy B. Ward wskazuje na umocowanie stwierdzeń z Praw w innym platońskim dziele - Timajosie ${ }^{72}$. Człowiek tam przedstawiony zostaje stworzony na podobieństwo bogów i boskiego logosu, obdarzony także pożądaniami, nad którymi powinien panować, ponieważ zależy od tego sprawiedliwe życie (Tim. 42A-B). Stworzywszy mężczyznę i kobietę, bogowie wyposażyli ich w organy płciowe ukierunkowane na przekazywanie życia w nasieniu (mężczyzna) oraz na przyjmowanie go i rodzenie dzieci (kobieta) (Tim. 91A-D). Oboje oni pozostają niespełnieni, jeśli nie łączą się w tym wspólnym akcie. Opowiadając o stworzeniu płci męskiej i żeńskiej, Platon określa wyraźnie jej cel, którym jest prokreacja, stanowiąca podstawę do odrzucenia relacji homoseksualnych w Prawach. Tam także Platon opisuje relacje homoseksualne jako szkodliwe dla społeczności, ponieważ promujące rozwiązłość.

Przykłady wskazujące na to, że za prawami natury ukrywa się coś więcej niż tylko zwyczaj kulturowy, można by mnożyć. Owidiusz, opisując miłość lesbijską, wkłada w usta Ifis dramatyczny monolog, w którym przekonuje ona siebie, aby wyrzec się swojej beznadziejnej miłości do Jante (Metam. 745-761). Jest kobietą i powinna szukać miłości jak inne kobiety. Jej uczucie nie ma szans na spełnienie, bo choć od ukochanej nie dzieli jej ani mąż, ani ojciec, ani nawet bogowie, którzy wysłuchują jej próśb, jest jeszcze inna siła stojąca na ich drodze. To natura, potężniejsza od nich wszystkich, która nie chce, aby obie kobiety połączyła miłość i wspólny związek (non

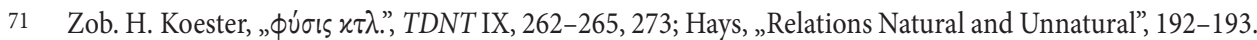

72 Ward, „Why Unnatural?”, 267. 
vult natura, potentior omnibus istis $)^{73}$. Owidiusz przedstawia ją tu jako potężniejszą nie tylko od ludzi, ale i od bogów, siłę, która wyznacza ramy ludzkiego życia i relacji.

Z kolei rzymski poeta Fedrus, odwołując się do wersji mitu o stworzeniu, udziela w swoich Bajkach prostej odpowiedzi na pytanie, skąd wzięły się kobiety uprawiające miłość z kobietami oraz zniewieściali mężczyźni (tribadas et molles mares). Przypisuje on męskie i żeńskie zachowania homoseksualne błędowi Prometeusza. Ten przez dłuższy czas pracował nad męskimi i żeńskimi narządami płciowymi (naturae partes), które wstydliwie ukrywamy pod ubiorem, aby dopasować je do odpowiednich ciał. Zaproszony jednak na kolację przez Bachusa, upił się tam nektarem i po powrocie do domu omyłkowo umieścił na mężczyznach żeńskie, a na kobietach męskie organy płciowe. Stąd według autora wzięły się zdeprawowane przyjemności, które są pożywką dla pożądania ${ }^{74}$.

Pseudo-Lukian, także odwołując się do mitu o stworzeniu, wskazuje na Afrodytę, matkę wszystkich ludzi, która jest prawdziwym wzorem kobiecości i która pomaga mężczyznom pozostawać męskimi, do czego się narodzili. To Afrodyta odpowiada za ocalenie kruchego ludzkiego życia od śmierci i przemijania przez to, że stworzyła mężczyznę zdolnego do produkowania nasienia i kobietę, która je przyjmuje. Bogini obdarzyła ich oboje wzajemnym pożądaniem i połączyła ze sobą świętym prawem

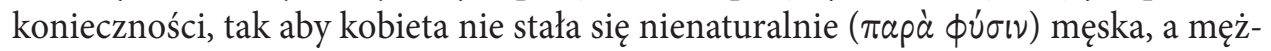
czyzna niestosownie kobiecy. Dzięki temu trwa następstwo pokoleń, a żaden mężczyzna nie może powiedzieć, że narodził się $\mathrm{z}$ innego mężczyzny ${ }^{75}$. W tekście tym natura wyraźnie łączy się z rozróżnieniem płciowym, za którym stoi wola bóstwa związana z przekazywaniem życia.

Sam Winkler, argumentując za odczytaniem natury w kluczu kulturowym u starożytnych, podaje dwa przykłady, które wydają się podważać jego pozycję ${ }^{76}$. Autor cytuje Senekę (Ep. 122.7-8), który jako przeciwne naturze kwalifikuje zachowanie mężczyzn przebierających się w kobiece stroje i starających się wyglądać jak młodzi chłopcy. Winkler słusznie wiąże tu naturę z przyjmowanym wówczas wzorcem męskości, traktując ją jako normę kulturową, lecz zupełnie nie zwraca uwagi na fakt, że Seneka nadaje jej także kwalifikację moralną. Autor starożytny stwierdza, że zachowania homoseksualne łączą się z wadami, luksusem i zbytkiem, wynikając z zepsucia. Porównuje je także do hodowania róż w zimie lub drzew owocowych na murach, co nie oznacza już normy kulturowej, lecz postawy niewspółgrające z istniejącymi prawami i procesami biologicznymi. Pożądanie rzeczy wbrew naturze prowadzi ostatecznie do porzucenia dróg natury, co Seneka porównuje dalej do odwrócenie porządku dnia i nocy (Ep. 122.9). Zachowania homoseksualne wydają się być zatem

Owidiusz, Metam. 9.758.

Fedrus, Fabulae 4.16.

Ps-Lukian, Am. 19.

Winkler, The Constraints of Desire, 21. 
przeciwne naturalnemu przeznaczeniu oraz procesom biologicznym, mającym miejsce w świecie. Porównanie do drzew, które nie wydają owoców na murach, może także przywoływać obraz współżyjących ze sobą mężczyzn, którzy marnują swoje, dające życie nasienie. Związki takie są bezproduktywne i jałowe.

W odniesieniu do Diona Chryzostoma Or. 7, tekstu, który mieliśmy już okazje widzieć, Winkler dostrzega $\mathrm{z}$ kolei jedynie walkę $\mathrm{z}$ hołdowaniem przyjemności związanej z bogactwem oraz krytykę elit i klas rządzących ${ }^{77}$. W jaki sposób człowiek gubiony przez brak opanowania i nienasycenie, prowadzące do kolejnych wad i postaw homoseksualnych, łamie u Diona Chryzostoma normy kulturowe? Uwodząc cieszące się szacunkiem kobiety i chłopców z dobrych rodzin. Oczywiście jest to pogwałcenie porządku społecznego, lecz opiera się on na trwalszym prawie, noszącym w sobie cechy obiektywności i uniwersalnej celowości, które pozwala zakwalifikować takie zachowanie jako wykroczenie typu moralnego. Potępienie tego typu postaw znajdujemy przecież nie tylko w kulturze grecko-rzymskiej, ale żydowskiej i wielu innych. Dion Chryzostom odrzuca dalej prostytucję i związki homoseksualne jako nienaturalne, ponieważ są to bezproduktywne i bezowocne fizyczne połączenia, które zamiast życia niosą zniszczenie (Or. 7.134, 136, 149). Dion przez odniesienie do prawa natury, walczy wręcz z kulturą swoich czasów i zakorzenionymi w niej złymi zwyczajami, które prowadzą do coraz większego zepsucia. Chce je zmieniać przez odpowiednie regulacje i troskę rządzących, podobnie jak Platon w swoich Prawach (Or. 7.137). Powołuje się przy tym na wspólną godność wszystkich ludzi wobec Boga, który obdarzył nas rozumem i znajomością dobra oraz zła (Or. 7. 138). Tylko wyrwanie wypowiedzi Diona Chryzostoma z kontekstu pozwala stwierdzić, że autor traktuje tu naturę jako normę kulturową, podczas gdy w rzeczywistości umieszcza on ją w szerszej perspektywie cnoty, godności człowieka oraz praw boskich. Pojęcia

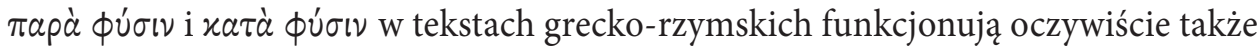
jako markery kulturowe, ale nie da się, jak czyni to Winkler, sprowadzić ich tylko do tego wymiaru ${ }^{78}$.

Świadczą o tym także teksty żydowskie, jak choćby obficie korzystający z Platona i łączący filozofię z Biblią Filon Aleksandryjski. Filon w De Abrahamo 133-136, podobnie jak Platon, a później Paweł, nie czynni żadnej różnicy między pasywnym a aktywnym homoseksualizmem. Autor, jak to już zaznaczyliśmy, opisuje mieszkańców Sodomy, wiążąc ich zachowanie z wszelkiego typu wadami: rozwiązłością, obżarstwem, pijaństwem i nieutemperowanym korzystaniem z przyjemności, wynikającymi z bogactwa, w którym żyli (Abr. 133-134). Zaowocowało to zwierzęcym wręcz zachowaniem, rozbijaniem małżeństw i relacjami między mężczyznami, z któ-

77 Winkler, The Constraints of Desire, 21-22.

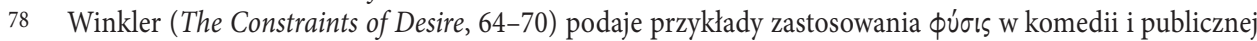
mowie, gdzie termin mógł oznaczać indywidualną naturę człowieka, silną inklinację, a nie uniwersalne prawo, któremu należy się poddać. 
rych nie mogło się zrodzić żadne potomstwo, a które wynikały z niepohamowanych żądz (Abr. 135). Mężczyźni przyzwyczaili się do bycia traktowanymi jak kobiety, nie tylko stając się zniewieściałymi i delikatnymi, ale przeistaczając się wręcz w kobiety, upadlając swoje dusze i obracając się w przyczynę upadku innych (Abr. 136).

Ward dostrzega pokrewieństwo słownictwa i myśli Filona z platońskim Fajdrosem (250E-251A), opisującym dusze oddające się pożądaniu i nienaturalnej

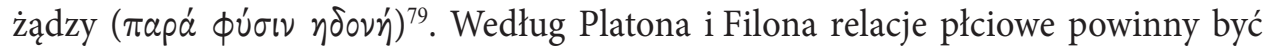
także ukierunkowane na dawanie życia (Abr. 136-137; Leg. 838E). Gdyby zależało to od zepsutych mężczyzn, ludzkie miasta opustoszałby jak pod wpływem zarazy ( $A b r$. 136). Filon porównuje ich do pozbawionych umiejętności rolników, którzy sieją tam, gdzie nie można spodziewać się żadnych plonów (Contempl. 62). Na szczęście Bóg, litując się nad ludzkością, wzmocnił naturalny pociąg między mężczyzną i kobietą, służący rodzeniu dzieci (Abr. 137). Z tego samego względu Filon potępia pedera-

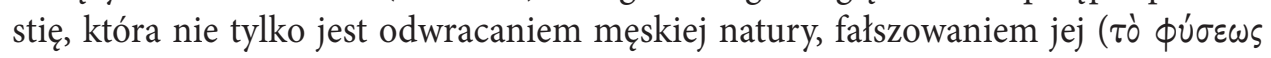

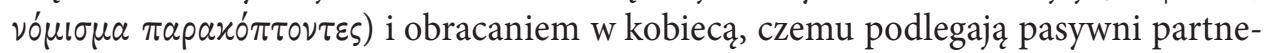
rzy (Spec. 1.325; 3.37-38), ale także marnowaniem życiodajnego nasienia, co czynią

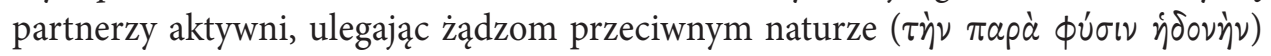
(Spec. 3.39). Praktykujący relacje homoseksualne, są pierwszymi do wykluczenia ze świętej społeczności (Spec. 1.325).

Idąc dalej śladem żydowskich konotacji prawa natury, Testament Neftalego stwierdza, że Bóg uczynił wszystkie rzeczy dobrymi według ich porządku (2.8). Tak jak słońce, księżyc i gwiazdy nie zmieniają swojego biegu, tak też człowiek nie powinien zmieniać praw Bożych swoim nieuporządkowanym postępowaniem (3.2). Poganie zapomnieli o Stwórcy i porządek ten odwrócili, oddając się, tak jak w Rz 1,23, bałwochwalstwu (3.3). Wymownym przykładem tego błędu jest zachowanie mieszkańców Sodomy. Odeszli oni od prawa natury, którego strzec mają Izraelici (3.4-5). Natura zostaje tu wyraźnie powiązana z porządkiem stworzenia i zamysłem Stwórcy ${ }^{80}$.

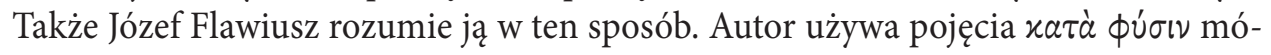
wiąc o kobiecym cyklu (Ant. 1.322; 3.261, 275) oraz łączeniu się mężczyzny i kobiety w związku małżeńskim dla prokreacji (Ap. 2.199). Flawiusz mówi tu o Prawie żydowskim, które opiera się na prawie natury, zabraniając związków mężczyzn z mężczyznami i karząc je. Autor nazywa je dalej przeciwnymi naturze i powodowanymi

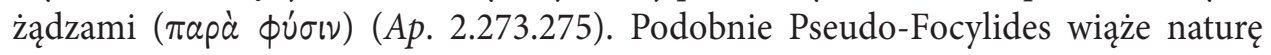
z prokreacją (175-176), przypisując związkom homoseksualnym przekraczanie jej praw (190-191). Także w tym przypadku Ward dostrzega odniesienie do Platona (Leg. 636C) $)^{81}$.

\footnotetext{
79 Ward, „Why Unnatural?”, 270.

80 DeYoung („The Meaning of 'Nature’ in Romans 1”, 433) uznaje ten tekst za szczególnie bliski Rz 1,26-27 wraz z Mdr 13,1.

81 Ward, „Why Unnatural?”, 276.
} 
Pawłowy dyskurs na temat relacji homoseksualnych jako niezgodnych z naturą przywodzi zatem na myśl Platona i autorów żydowskich, takich jak Filon, Józef Flawiusz i Pseudo-Focylides. Można go również skojarzyć z poglądami stoików, uczących, że właściwe użycie dóbr tego świata powinno wiązać się ich naturalnym przeznaczeniem $^{82}$. Brooten wskazuje, że koncepcja prawa naturalnego - w szerokim rozumieniu prawa moralnego, które funkcjonuje, choć niespisane przez żadnego legislatora - to inwencja stoicka, która odwołuje się do koncepcji boskiego logosu przenikającego stworzony świat, umożliwiając człowiekowi poznanie jego praw, dostarczając norm sprawiedliwości i gwarantując, że żyjący według nich osiągną szczęście. Koncepcja ta uległa przeobrażeniu pod wpływem platońskim, z czego wyłonił się obraz transcendentnego bóstwa ordynującego prawo naturalne ${ }^{83}$. Z boską wolą wiąże się także instytucja małżeńska i rodzenie dzieci. Jedno i drugie w starożytnych tekstach filozoficznych i prawnych posiada wyraźne odniesienie do natury ${ }^{84}$.

$\mathrm{Na}$ tej zasadzie hellenistyczni myśliciele i autorzy uważali relacje homoseksualne za niezgodne z naturą, która jest czymś więcej niż synonimem życia biologicznego. Natura to świat, w którym odbija się boski zamysł stwórczy, którego odczytanie jest $\mathrm{z}$ kolei kluczem do szczęśliwego życia. Życie zgodne z naturą to życie zgodne z boskim logosem, logiką, która przenika całą stworzoną rzeczywistość ${ }^{85}$. Pawłowi daleko do stoickiego intelektualizmu, ale może dzielić ze stoikami przekonanie o Bożych prawach rządzących światem stworzonym ${ }^{86}$. Jak powszechnie twierdzą komentatorzy Listu do Rzymian, koncepcja natury, jaka pojawia się w Rz 1,26-27, to coś więcej niż tylko naturalna kolej rzeczy lub konwencja społeczna ${ }^{87}$. Argumentacja apostoła dobrze rezonuje z różnego rodzaju szkołami filozoficznymi, które definiowały naturę

82 Na ten temat zob. Fredrickson, „Natural and Unnatural Use in Romans 1:24-27”, 203-205.

83 Brooten, Love Between Women, 269. Z odniesieniem do: Striker, „Origins of the Concept of Natural Law”, 79-94; Horsley, „The Law of Nature in Philo and Cicero", 35-59.

84 Zob. Brooten, Love Between Women, 270, 271 plus przyp. 12 na temat bibliografii związanej z koncepcją prawa naturalnego i jej aplikacją w Biblii. Więcej na temat prawa naturalnego zob. w: Skinner, „New Testament Ethics and Natural Law”, 8-17; McKenzie, „Natural Law in the New Testament”, 3-13; Greenwood, „Saint Paul and Natural Law”, 262-279; Johnson, „Is There a Biblical Warrant for Natural-Law Theories”, 185-199; Remus, „Authority, Consent, Law”, 5-18; Ball, „Law Natural”, 140-165; Weinreb, Natural Law and Justice; Hittinger, „The Recovery of Natural Law and the 'Common Morality”, 62-74; Covell, The Defence of Natural Law; George (red.), Natural Law Theory; Curran - McCormick (red.), Natural Law and Theology; Biggar - Black (red.), The Revival of Natural Law; Paul - Miller - Paul (red.), Natural Law and Modern Moral Philosophy; Cherry, Natural Law and the Possibility of a Global Ethics; Bussey, „Natural Law", 5-28.

85 Na temat natury i logosu u stoików zob. Köster, „фúøı", 264-265; Fredrickson, „Natural and Unnatural Use in Romans 1:24-27", 205-206.

86 Na temat podwójnego, żydowskiego i grecko-rzymskiego charakteru argumentacji Pawła zob. Dunn, Romans, 64; Fitzmyer, Romans, 286; Byrne, Romans, 77; Himbaza - Schenker - Edart, The Bible on the Question of Homosexuality, 96-97.

87 Dunn, Romans, 64; Fitzmyer, Romans, 286; Cranfield, A Critical and Exegetical Commentary on the Epistle to the Romans, 125-126; Moo, The Epistle to the Romans, 114-115; Schreiner, Romans, 94-95; Na temat pojęcia natury w Rz 1 zob. także DeYoung, „The Meaning of 'Nature' in Romans 1”, 429-441. 
jako prawdziwą i niezmienną strukturę rzeczy (Heraklit), określały ją jako niematerialną esencję wszystkiego (Platon) czy formę i siłę poruszającą rzeczy stworzone, decydującą o ich celowości, użyteczności i pięknie (Arystoteles) ${ }^{88}$. Stoicy nadawali фúøıs wręcz cechy boskie, opisując ją jako kosmiczne principium życia, które przenika cały wszechświat i strzeże jego porządku ${ }^{89}$.

$\mathrm{W}$ podobnym sensie natura pojawia się u Filona ${ }^{90}$. Występuje ona w jego pismach w upersonifikowanej formie jako stwórca i ta, która podtrzymuje świat w istnieniu, wyposażona $\mathrm{w}$ boskie cechy niestworzoności i nieśmiertelności ${ }^{91}$. Obdarza ona człowieka swoimi darami, a nawet kształtuje jego formę ${ }^{92}$. Oczywiście dla Filona prawo natury ściśle wiąże się z Bożym prawem, które jest takie samo dla wszystkich i leży u podstaw stworzenia ${ }^{93}$. Autor może zatem stwierdzić, że Abraham wypełnił wszystkie przykazania Prawa, nie te spisane, ponieważ te jeszcze nie istniały, lecz te wpisane w naturę i ludzkie serce ${ }^{94}$. U autorów Księgi Mądrości oraz Trzeciej

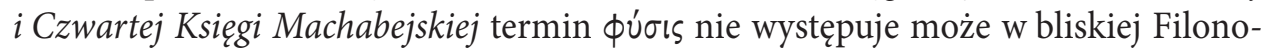
wi formie upersonifikowanej, kosmicznej siły, ale także wiąże się z Bożym dziełem stworzenia. Oznacza on istoty stworzone (3 Mch 3,29), cielesność, aspekt fizyczny (4Mch 1,40), naturę jako dawcę darów $(4 M c h 5,8.9)$, porządek rzeczy ustanowiony przez Boga (4 Mch 5,25), fundament więzi braterskich i rodzicielskich (4 Mch 13,27; $15,13.25 ; 16,3)$, cechy stworzeń (Mdr 7,20), właściwości fizyczne elementów składowych wszechświata (Mdr 19,20) oraz charakter człowieka otwartego na poznanie Boga (Mdr 13,1) $)^{95}$.

U Pawła natura prócz Rz 1,26 pojawia się jeszcze w Rz 2,14, gdzie określa swoisty kompas postępowania moralnego pogan, kolej rzeczy wynikającą z przynależności etnicznej (brak obrzezania u pogan w Rz 2,27 i przywileje Żydów w Ga 2,15; Rz 11,21.24), zwyczaj kulturowy noszenia długich włosów (który jednak ma swoje oparcie w charakterze kobiety i mężczyzny) (1 Kor 11,14) czy rzeczywisty charakter bóstwa $(\mathrm{Ga} 4,8)$. W tekstach tych pojawia się natura w rozumieniu charakteru etnicznego i ludzkiego, jednak trudno zupełnie odłączyć ją od Bożego stwórczego i zbawczego zamysłu. W Rz 2,14 na przykład mowa jest o poganach, którym natura służy za intuicję postępowania moralnego. Richard B. Hays zwraca uwagę na żydowsko-hellenistyczne tło języka Pawła w Rz 1,26-27 i na fakt, że nawet uznanie, iż Paweł opisuje

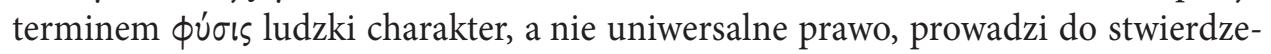

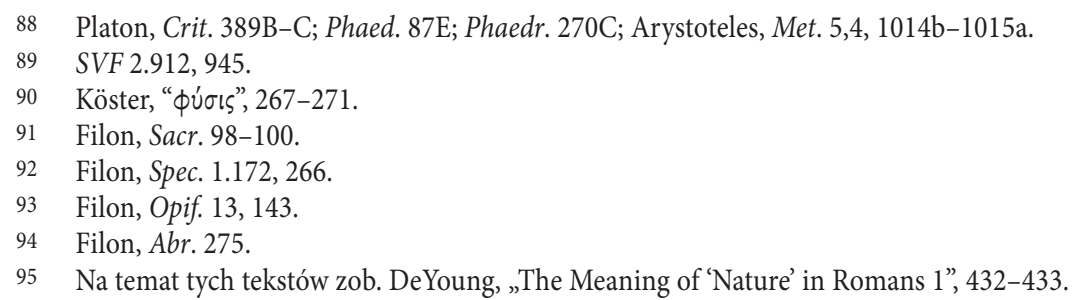


nia, że z charakterem tym kłócą się relacje typu homoseksualnego ${ }^{96}$. Charakteru tego nie da się także odłączyć od szerokiego kontekstu teologii stworzenia, dominującego w Rz 1,18-32. Podobnie konstatuje James B. DeYoung. Przebadawszy różne obszary, w których „natura” ( $\phi \dot{\sigma} \sigma \varsigma)$ pojawia się kulturze grecko-rzymskiej, judaizmie hellenistycznym oraz tekstach chrześcijańskich, argumentuje on za jej żydowskim kolorytem u Pawła i za jej powiązaniem z charakterem człowieka, determinowanym przez Boże dzieło stwórcze ${ }^{97}$.

Paweł oczywiście nie ubóstwia natury, która pozostaje wciąż niedoskonałym odbiciem Bożego obrazu i jest zraniona grzechem. Wizję Stwórcy oraz godność stworzenia według apostoła wyczytać można z kart Księgi Rodzaju oraz z objawienia przychodzącego w Chrystusie. Wymownym przykładem nieregularności powstających na poziomie świata natury są relacje homoseksualne w świecie zwierzęcym, które według Jacka Rogersa wskazują na genetyczną determinację i naturalność homoseksualizmu ${ }^{98}$. Ci, którzy postulują tak pojętą „naturalność” relacji homoseksualnych, popełniają jednak podwójny błąd. Po pierwsze utożsamiają naturę ze światem biologicznym i zwierzęcym, podczas gdy dla Pawła i cytowanych autorów żydowskich jest ona rzeczywistością przenikniętą Bożą logiką i zamysłem stwórczym - to nie tylko życie na poziomie ciała i duszy biologicznej, ale także na płaszczyźnie pierwiastka Bożego, ducha. Po drugie, mówiąc o naturalności homoseksualizmu występującego w świecie zwierzęcym, utożsamia się w ten sposób księgę natury z księgą objawienia, a świat zwierząt staje się wzorem życia dla człowieka. Raz jeszcze wzór ludzkiego życia zostaje objawiony przez Boga w akcie stworzenia mężczyzny i kobiety, a narracja z Księgi Rodzaju stanowi jedną z najważniejszych skrypturystycznych inspiracji argumentacji apostoła. Między innymi ku niej zwrócimy się w ostatnim kroku analizy Pawłowej inventio w Rz 1,26-27.

\section{Pisma i teologia stworzenia jako podstawa dla wypowiedzi Pawła w Rz 1,26-27}

W swojej argumentacji w Rz 1,18-32 Paweł posługuje się, jak widzieliśmy, kategoriami oraz pojęciami właściwymi dla kultury grecko-rzymskiej, które przenikają także do hellenistycznego judaizmu. Wśród nich nie może oczywiście zabraknąć odwołania do Pisma, które jest podstawowym punktem odniesienia dla myśli apostoła.

\footnotetext{
96 Hays, „Relations Natural and Unnatural”, 197. Przyimek rapá nie oznacza tu wyjścia poza czy przesady, z jaką traktuje się naturę, ale sprzeciwienie się jej, jak w innych tego typu określeniach w tekstach hellenistycznych (s. 198).

97 DeYoung, „The Meaning of 'Nature' in Romans 1”, 429-435, 437-439. Zob. także Hays, „Relations Natural and Unnatural", 192-194.

98 Rogers, Jesus, the Bible, and Homosexuality, 77, 81.
} 
Podczas gdy Filon w Abr. 133-137 łączy krytykę postaw homoseksualnych z historią Sodomy (Rdz 19,1-25), Paweł nie odwołuje się wprost do znanych tekstów Starego Testamentu, które potępiają tego typu postawy ${ }^{99}$. Jest to zrozumiałe, biorąc pod uwagę strategię argumentacyjną apostoła, próbującego dotrzeć ze swoim przesłaniem na temat powszechnego zepsucia ludzkości zarówno do pogan, jak i do Żydów. Nadaje się do tego doskonale Księga Mądrości, która z natury swej jest dziełem wykorzystującym styk kulturowy świata hellenistycznego i objawienia Starego Testamentu $^{100}$. To na nią właśnie powszechnie wskazuje się jako pierwsze źródło inspiracji apostoła w Rz 1,18-32 ${ }^{101}$.

Gdzie można dopatrzeć się kontaktów między analizowanym fragmentem Listu do Rzymian a Księgą Mądrości? William Sanday i Arthur C. Headlam w swoim komentarzu podają zestawienie tekstów z Mdr 12-14, które pod względem słownictwa i myśli korespondują z Rz 1,18-32 ${ }^{102}$. W Rz 1,20 Paweł mówi o niewidzialnych przy-

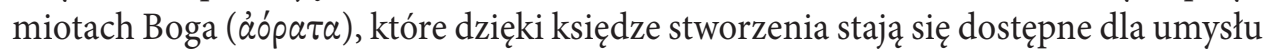

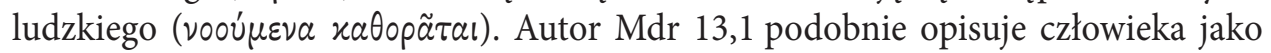
z natury ( $\phi \dot{\sigma} \sigma \varepsilon l)$ zdolnego do rozpoznania Stwórcy z Jego widzialnych dzieł ( $\check{\chi} \tau \tilde{\omega} \nu$

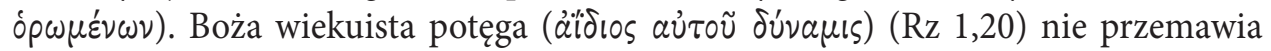
jednak do tych, którzy zachwycają się potęgą stworzeń (dúvauı) (Mdr 13,4), czcząc je zamiast Stwórcy (Rz 1,21-23; Mdr 13,1-5). Tymczasem, w czym zgadzają się znów Paweł i autor Księgi Mądrości, z wielkości i piękna stworzeń, przez podobieństwo poznaje się ich Sprawcę (Mdr 13,5). Ludzie, którzy stworzeni na obraz Bożej wieczności (äï̊ótns) (Mdr 2,23), lekceważą ją, nie mogą się zatem wymówić od winy, kimkolwiek są (Rz 1,20; Mdr 13,8). Paweł nazywa ich znikczemniałymi w swoim myśle-

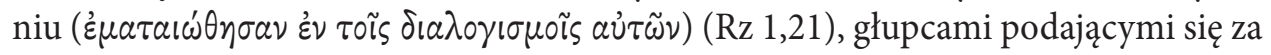
mądrych (Rz 1,22). Podobnie autor Mdr 13,1 mówi o nich jako głupcach ( $\mu$ átaı zwiedzionych, nierozsądnych dzieciach (Mdr 12,24-25) czy o tych, którzy dysponując ogromną wiedzą o wszechświecie, nie odnaleźli w nim jego Władcy (Mdr 13,9).

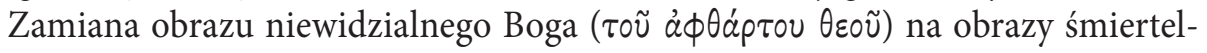
nego człowieka ( $\phi \theta a \rho \tau 0 \tilde{u} a ̀ v \theta \rho \omega ́ \pi 0 u)(R z 1,23)$ to zdrada nieśmiertelnego Ducha,

99 Philip F. Esler („The Sodom Tradition in Romans 1:18-32”, 4-16) jako podłoże dla Pawłowych rozważań w Rz 1,26-27 proponuje jednak historię o Sodomie zapisaną w Księdze Rodzaju, funkcjonującą w zbiorowej pamięci słuchaczy wspólnoty chrześcijańskiej w Rzymie.

$100 \mathrm{Na}$ temat charakteru Księgi Mądrości i jej powiązania z hellenizmem zob. Reese, Hellenistic Influence on the Book of Wisdom and Its Consequences; Winston, The Wisdom of Solomon, 12-64; Collins, Jewish Wisdom in the Hellenistic Age, zwł. 133-157, 178-221.

101 Sanday - Headlam, A Critical and Exegetical Commentary on the Epistle to the Romans, 51-52; Hyldahl, „Reminiscence of the Old Testament at Romans 1:23”, 285-288; Dunn, Romans, 72-73; Byrne, Romans, 64-65; Longenecker, The Epistle to the Romans, 193-195; Brooten, Love Between Women, 294-298; Linebaugh, „Announcing the Human”, 214-237; Lucas, „Distinct Portraits”, 61-82. Zob. także Krawczyk, „Michael Riffaterre's 'Interpretant' Reinterpreted”, 261-277.

102 Sanday - Headlam, A Critical and Exegetical Commentary on the Epistle to the Romans, 51-52. Zob. takzie Witherington - Hyatt, Paul's Letter to the Romans, 63. 


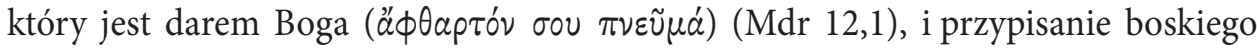

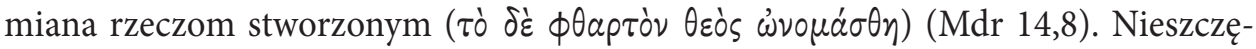
sna cześć oddawana bożkom wypełnia krytykę nierozumnej ludzkości w Rz 1,23 i w Mdr 13,10-15,19. Prowadzi ona także do głębokiego upadku moralnego rodzaju ludzkiego. Nieuznanie Stwórcy autor Księgi Mądrości diagnozuje jako przyczy-

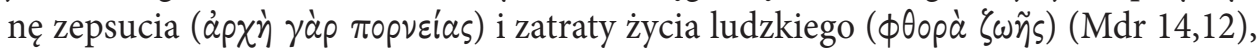
niezachowywania czystości ( $\varkappa$ ađapós) życia i małżeństw, szerzącego się cudzołóstwa i zabójstwa (Mdr 14,24), a także szeregu grzechów dotykających ludzkiej seksualności: relacji homoseksualnych ( $\gamma \varepsilon v \varepsilon ́ \sigma \varepsilon \omega \varsigma ~ \varepsilon ่ v a \lambda \lambda \alpha a \gamma \eta \dot{)}$ ), rozprzężenia w małżeństwach, cudzołóstwa i rozpusty $(\operatorname{Mdr} 14,26)^{103}$. Podobnie Paweł w braku uznania Stwór-

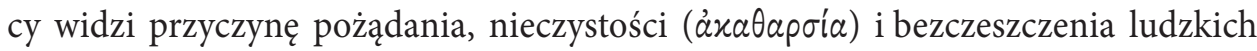
ciał (Rz 1,24) przez żeńskie i męskie akty homoseksualne ( $\mathrm{Rz}$ 1,26-27). Katalog win z Mdr 14,25-26 i ten z Rz 1,29-31 przekonują, ile zła bierze się z odrzucenia praw Boga Stwórcy. Nic dziwnego, że autor Księgi Mądrości nazywa ten akt początkiem, przyczyną i szczytem wszelkiego zła (Mdr 14,27).

Rz 1,19-21 to według Jamesa D.G. Dunna praktycznie streszczenie żydowskiej polemiki z idolami, zapisanej w Mdr 13,10-15,19104. Znajdujemy tu także wspólną myśl na temat destrukcyjnego wpływu lekceważenia stwórczych praw Boga. Zarówno według autora Księgi Mądrości, jak i Pawła prowadzi ono do poniżenia i zepsucia człowieka, uruchamia procesy godzące w jego moralność i seksualność, a także przyczynia się do rozkładu życia społecznego, czego wymownym przykładem są katalogi wad z Mdr 14,25-26 i Rz 1,29-31. To nie grzech relacji homoseksualnych sam w sobie odpowiedzialny jest za zniszczenie jednostki i społeczności, ale leżące u jego podstaw łamanie praw Boga Stwórcy i odrzucenie $\mathrm{Go}^{105}$. Człowiek, z natury zdolny do odczytania obecności Boga i jego porządku w stworzonym świecie, porzuca go, sam ulegając wynaturzeniu. Pojęcie natury ( $\phi \dot{\sigma} \sigma \varsigma)$, pojawiające się w Mdr 13,1, stanowi dobry punkt wyjścia dla interpretacji Pawłowego sądu w Rz 1,26-27 na temat relacji homoseksualnych jako sprzecznych z naturą. Sprzeciwia im się charakter i konstytucja człowieka, otwarte na poznanie Boga, noszące w sobie Boży zamysł i celowość. Joseph A. Fitzmyer wskazuje na inspirację dla Pawłowej myśli na temat kary spadającej na uprawiających relacje homoseksualne (Rz 1,27) także w Mdr 11,16, gdzie mowa jest o tym, że każdy karany jest tym, czym grzeszy (lex talionis) ${ }^{106}$.

W jaki sposób Paweł przyswoił sobie koncepcje obecne w Księdze Mądrości? Sanday i Headlam sugerują, że je studiował, inni wskazują na ich obecność w ho-

\footnotetext{
103 Brooten, Love Between Women, 296-297.

104 Dunn, Romans, 72.

105 Uniwersalny aspekt zepsucia ludzkości i jego przyczyny, nie aspekt etniczny, rozróżnienia między Żydami i poganami, jest podstawowym motywem łączącym myśl Pawła w Rz 1,26-27 z Mdr 13-15. Kontra Brooten, Love Between Women, 298.

106 Fitzmyer, Romans, 288. Podobnie w odniesieniu do Rz 1,24 Jewett - Kotansky, Romans, 167.
} 
miliach synagogalnych, których mógł słuchać apostoł ${ }^{107}$. Kontakty leksykalne i treściowe między Rz 1,18-32 i Mdr 12-15 rzeczywiście są uderzające, lecz używane tu słownictwo należy do popularnych terminów filozoficznych, które Paweł mógł zaczerpnąć ze środowiska hellenistycznego judaizmu, mocno nasiąkniętego kulturą grecko-rzymską ${ }^{108}$. Podobnie popularne jest powiązanie grzechów homoseksualnych z bałwochwalstwem, które znajdujemy np. w Wyroczniach Sybillińskich. W dziele tym Izrael różni się od pogan faktem, że nie czci bożków, lecz wznosi ręce ku prawdziwemu Bogu i uświęca swe ciało przez obmycia, szanuje świętość łoża małżeńskiego i nie uprawia pederastii (Sib. Or. 3.584-600). W obliczu sądu Bożego naród wybrany wezwany jest do unikania bałwochwalstwa i relacji między mężczyznami oraz aborcji i porzucania dzieci, które są szczególną przyczyną gniewu Bożego (Sib. Or. 3.764-766) ${ }^{109}$. W tym ostatnim fragmencie pojawia się nawiązanie nie tylko do relacji homoseksualnych i bałwochwalstwa, ale także do gniewu Bożego, który stanowi motyw przewodni Rz 1,18-32. Można zatem przyjąć, że Paweł korzysta ze wspólnych hellenistycznemu judaizmowi idei, jasno wyartykułowanych w Księdze Mądrości.

Księga Mądrości to zresztą nie jedyny punkt odniesienia dla myśli apostoła w Rz 1,18-32. Paweł, opisując zamianę prawdziwego Boga na pogańskie bożki, odwołuje się także do tradycji zawartych w Ps 105,20 i Jr 2,11 (LXX), które używają tego samego czasownika $\alpha \lambda \lambda \alpha \dot{\sigma} \sigma \omega$ dla opisania grzechu bałwochwalstwa, szerzącego się w Izraelu ${ }^{110}$. Dunn w kontekście tym wskazuje także na Iz 44,9-20 oraz List Jeremiasza ${ }^{111}$. Przytacza się tu także prawa Przymierza - mające zapewnić Izraelowi posiadanie ziemi obiecanej i długie życie w niej - wśród których znajduje się ścisły zakaz sporządzania idoli (Pwt 4,16-19). Zawarte tam sformułowania, dotyczące czy-

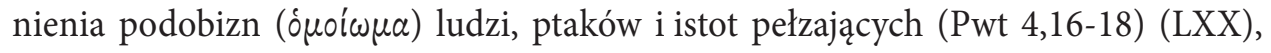
przywołują te $\mathrm{z}$ Rz $1,23^{112}$.

Brooten optuje jeszcze za bezpośrednim odniesieniem do Kpł 18,22 i 20,13 w Rz 1,26-27 $7^{113}$. Według autorki apostoł nie cytuje wprost źródeł kapłańskich, ale odwołuje się do nich w trzech punktach: w słownictwie związanym z bezwstydem

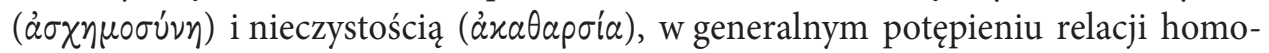
seksualnych między mężczyznami, bez rozróżniania charakteru ich uczestników,

Sanday - Headlam, A Critical and Exegetical Commentary on the Epistle to the Romans, 52; Longenecker, The Epistle to the Romans, 194-195.

108 Collins, Jewish Wisdom in the Hellenistic Age, 205-213; M. Kowalski, „Apokaliptyczny gniew Boga”, 222-230.

109 W tekstach uderza powiązanie związków homoseksualnych z bałwochwalstwem, podobnie jak u Pawła.

110 Dunn, Romans, 72-73; Moo, The Epistle to the Romans, 108-109; Cranfield, A Critical and Exegetical Commentary on the Epistle to the Romans, 119.

111 Dunn, Romans, 61.

112 Cranfield, A Critical and Exegetical Commentary on the Epistle to the Romans, 119; Himbaza - Schenker Edart, The Bible on the Question of Homosexuality, 88-89.

113 Brooten, Love Between Women, 281. Podobnie Mueller, Homosexuality, Scripture, and the Church, 23. 
oraz w wyroku w postaci spadającej na wszystkich śmierci ${ }^{114}$. Pawła z Księgą Kapłańską łączyłyby także kategorie świętości, honoru i wstydu, nieczystości, hańby, a także ścisłe powiązanie aspektu kultycznego i moralnego. Aplikacja kategorii kultycznych przez apostoła służyłaby, podobnie jak w dziele kapłańskim, utrzymaniu rozróżnienia płci ${ }^{115}$. Trudno odmówić Brooten racji, prawa Księgi Kapłańskiej zapewne stanowią podłoże rozumowania apostoła, choć ich obecność widać lepiej w 1 Kor 6,9-10 i $1 \mathrm{Tm}$ 1,8-10. Kategorie kultyczne, czystość i nieczystość, oczywiście mają charakter moralny, stając się w Nowym Testamencie sposobem opisania także innych poza homoseksualizmem grzechów, które wykluczają ze wspólnoty z Bogiem ${ }^{116}$. Paweł, w przeciwieństwie do Księgi Kapłańskiej, włącza w swój opis także kobiety i nie mówi o śmierci fizycznej jako karze. Nie nawiązuje on wprost do kategorii z Księgi Kapłańskiej, ponieważ zależy mu na możliwie szerokiej płaszczyźnie potępienia zepsucia ludzkości. Dla rozróżnienia płci u apostoła znacznie lepszą bazą wydaje się być narracja Księgi Rodzaju, mówiąca o stworzeniu kobiety i mężczyzny, która stanowi zresztą podstawę dla Księgi Kapłańskiej i ma swoje paralele w przytaczanym już Timajosie Platona ${ }^{117}$.

Egzegeci, zwracając uwagę na odwołania do Księgi Rodzaju w Rz 1,18-32, wiążą je zasadniczo z kontekstem buntu i upadku człowieka ${ }^{118}$. Według Dunna apostoł w Rz 1,19-25 odwołuje się do Rdz 2-3, zaś wersety. 29-31 stanowią ilustrację dla stopniowego oddalania się ludzkości od Boga po grzechu pierworodnym. Konkluzja w Rz 1,32 to nic innego jak wypełnienie się zapowiedzi z Rdz 2,16 o śmierci, która zawisła nad odchodzącą od Bożych praw ludzkością ${ }^{119}$. Choć w Rz 1,19-32 nie pojawia się wprost cytat z Rdz 2-3, niemożliwe jest dla Żyda, jak twierdzi Dunn, myśleć o uniwersalnym upadku i zepsuciu ludzkości bez odwołania do Księgi Rodzaju ${ }^{120}$. Typowo żydowskie powiązanie między upadkiem człowieka i grzechami natury seksualnej znajdujemy zresztą nie tylko w Księdze Rodzaju (rozdz. 6), ale także w innych tekstach żydowskich ${ }^{121}$.

114 Brooten, Love Between Women, 282-283.

115 Brooten, Love Between Women, 288-294.

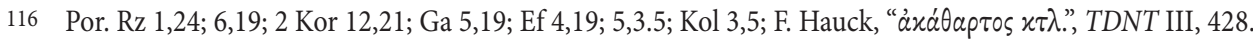

117 Na temat rozróżnienia płciowego w Księdze Kapłańskiej zob. Gagnon, The Bible and Homosexual Practice, 135-142.

118 Przeciw lekturze Rz 1,18-32 opartej na narracji o stworzeniu jest Dale B. Martin („Heterosexism and the Interpretation of Romans 1:18-32”, 332-355), który mówi o Pawłowym micie na temat związku idolatrii z homoseksualizmem, zastąpionym chrześcijańskim mitem o związku między grzechem pierworodnym i homoseksualizmem. W jeden i w drugi nikt już według autora nie wierzy (s. 339). Sam Martin nie posługuje się w swojej analizie Pawła kategoriami teologicznymi, eliminując w odniesieniu do relacji homoseksualnych pojęcia grzechu i odkupienia. Opiera się tylko na dyskursie społeczno-kulturowym, nakładając anachronicznie tę matrycę na Rz 1,26-27.

119 Dunn, Romans, 69-70.

120 Dunn, Romans, 72.

121 Dunn, Romans, 65-66 z odniesieniem do Jub. 4.22; 5.1-10; 7.21; 1 Hen 6-11, 86; TestRub 5; TestNeft 3.5; CD 2.18-21. 
Przyjmując możliwy związek uniwersalnego zepsucia człowieka w Rz 1,18-32 z historią upadku opisaną w Rdz 2-3, zwróćmy jednak uwagę na to, że w odniesieniu do grzechu natury homoseksualnej kluczowy jest dla Pawła także opis stworzenia człowieka z Rdz 1,27-28 (LXX) ${ }^{122}$. Słyszymy tam o powołaniu do życia mężczyzny

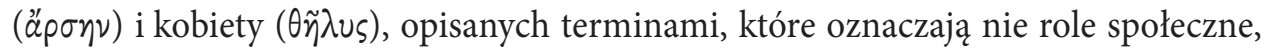
ale odpowiednio płeć męską i żeńską. Dodatkowo wiążą się one z dawaniem życia $\theta \tilde{\eta} \lambda u s$ etymologicznie pochodzi od rdzenia oznaczającego matczyną pierś, karmienie piersią ${ }^{123}$. Thomas R. Schreiner słusznie zwraca uwagę na fakt, że w Rz 1,26-27 Paweł

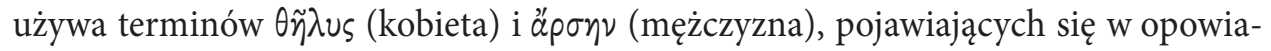
daniu o stworzeniu mężczyzny i kobiety (Rdz 1,27 LXX), co wskazuje na źródło jego myśli w Księdze Rodzaju ${ }^{124}$. Związki homoseksualne zacierają różnicę między mężczyzną a kobietą, ustanowioną Bożym dziełem stworzenia ${ }^{125}$.

Rozróżnienie to nie ma charakteru zwykłego ornamentu i nie dodaje jedynie różnorodności światu stworzonemu. Pozostaje ono na usługach przekazywania życia. W Księdze Rodzaju mężczyzna i kobieta zostają pobłogosławieni przez Boga jako płodni i wezwani do rozmnażania się, zaludniania ziemi i czynienia jej sobie poddaną. Mają panować nad ptactwem powietrznym, rybami morskimi i wszelkimi pełzającym stworzeniem $(\mathrm{Rz} 1$ 1,28). Słownictwo $\mathrm{z}$ nimi związane także pojawia się w Rz 1,23, ale w zgoła odmiennym kontekście. U Pawła stworzenie staje się obiektem czci, co jest owocem odejścia od prawdy o Bogu Stwórcy i porzucenia jego

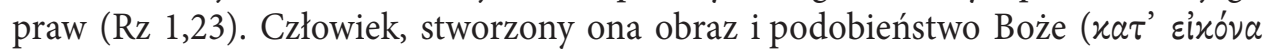

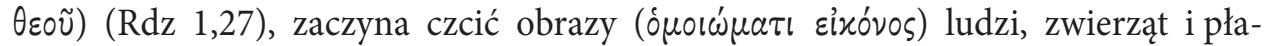
zów (Rz 1,23). To dodatkowe argumenty leksykalne za powiązaniem myśli Pawła w Rz 1,18-32 z Rdz 1,27-28 $8^{126}$. Idąc za modelem płciowości zapisanym w Księdze Rodzaju, Paweł może uważać związki homoseksualne wszelkiego rodzaju za nienaturalne, ponieważ nie są one zdolne do dawania życia, które dokonuje się tylko w relacji mężczyzny i kobiety. W tym także sensie kobieta i mężczyzna są stworzeni na obraz Boga - tak jak On są zdolni do przekazywania życia. Apostoł nie stwierdza tego wprost, ale można to wydedukować pośrednio z terminów $\theta \tilde{\eta} \lambda u \varsigma$ a a ăp $\sigma \nu$, jakich używa oraz z Rdz 1,28. Tego typu powiązania są zresztą obecne w kulturze hellenistycznej, widzieliśmy je u Platona (Leg. 838E-839A, 841D; Tim. 91A-D) oraz u autorów żydowskich, jak choćby Filona Aleksandryjskiego (Abr. 135-137; Contempl. 62; Spec. 3.39), Józefa Flawiusza (Ap. 2.199), czy Pseudo-Focylidesa (175-176).

Jak słusznie argumentują Innocent Himbaza, Adrian Schenker i Jean-Baptiste Edart, homoseksualizm na wiele sposobów zaciera obraz Boga Stwórcy wpisany

122 Gagnon, The Bible and Homosexual Practice, 288-292.

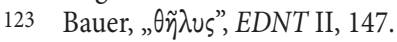

124 Schreiner, Romans, 94-95

125 Via and Gagnon, 78; Mueller, Homosexuality, Scripture, and the Church, 22.

126 Zob. także Stuhlmacher, Paul's Letter to the Romans, 37; Mueller, Homosexuality, Scripture, and the Church, 21-22. 
w człowieka według narracji Księgi Rodzaju. Prowadzi on do utraty ludzkiej wolności, ponieważ człowiek staje się niewolnikiem własnych żądz ( $\mathrm{Rz} 1$,23.24.26). Jego skutkiem jest poniżenie ludzkiego ciała, które jest Bożym darem. Wreszcie relacje homoseksualne niszczą jednoczący wymiar płciowości, jej różnorodność oraz celowość (Rz 1,24) $)^{127}$. W 1 Kor 11,3 Paweł opisuje wzajemne oddawanie się sobie kobiety i mężczyzny na podobieństwo relacji Trójcy, zaś w 1 Kor 11,7 mówi o kobiecie jako chwale mężczyzny, tej, która pozwala mu zrozumieć własną tożsamość i objawia jego godność. Bez komplementarności płci człowiek traci nie tylko odniesienie do wzoru Bożego, ale także przestaje siebie rozumieć ${ }^{128}$. Pozostaje także samotny, z dala od Boga i z dala od relacji, która została mu ofiarowana jako lekarstwo na pierwotną samotność (Rdz 2,18). Rozróżnienie płciowe zapisane w Księdze Rodzaju jest kluczowe dla więzi człowieka z Bogiem, dla relacji międzyludzkich i szczęścia jednostki. Będzie także podstawą dla praw kapłańskich zabraniających współżycia mężczyzn

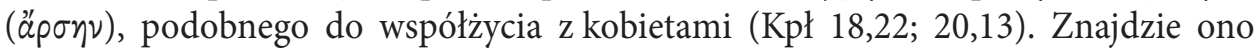
także odbicie w judaizmie rabinicznym, który - komentując Kpł 18,22 w perspektywie teologii stworzenia - będzie zabraniał zacierania różnic między płciami. Relacje homoseksualne (męskie i żeńskie) przekraczają ustanowione przez Boga granice między gatunkami i rodzajami stworzeń (cross-kulturowe tabu) ${ }^{129}$.

\section{Konkluzja: Paweł, kultura grecko-rzymska i tradycja żydowska na temat homoseksualizmu}

Kiedy Paweł w Rz 1,18-32 zdecydował się umieścić homoseksualizm między grzechami, które ściągają na człowieka gniew Boży, sprzymierzeńców takiej wizji mógł znaleźć zarówno w kulturze grecko-rzymskiej, jak i żydowskiej. Wbrew temu, co argumentuje Boswell, ta pierwsza wcale nie była tak tolerancyjna wobec postaw homoseksualnych, napiętnowując związki lesbijskie i penalizując w szczególny sposób pasywne role seksualne przyjmowane przez wolnych mężczyzn. Grecy i Rzymianie, podobnie jak apostoł, opisują miłość lesbijską jako niemoralną, to samo określenie aplikując także do stosunków między mężczyznami. Okradały one z męskości tego, kto odgrywał w nich pasywną rolę, właściwą kobiecie, ale także mężczyzna w roli aktywnej oskarżany był o demoralizację i demaskulinizację partnera. Miłość między mężczyznami nie służyła cnocie. Autorzy, tacy jak Platon, Dion Chryzostom, Filon, Józef Flawiusz czy Pseudo-Focylides, wiązali ją z rozwiązłością, brakiem samoopa-

\footnotetext{
127 Na te trzy wymiary grzechu zwraca uwagę Himbaza - Schenker - Edart, The Bible on the Question of Homosexuality, 99-104.

128 Kowalski, „Między darem Bożym a konstruktem społecznym”, 59-104.

129 Boyarin, „Are There Any Jews in 'the History of Sexuality'?”, 341-348; Brooten, Love Between Women, 65.
} 
nowania, pijaństwem i prostytucją. Oprócz penalizowania relacji homoseksualnych między wolnymi obywatelami, znacznie bardziej dotkliwą sankcją była towarzysząca im kwestia utraty honoru, dobra tak pożądanego przez starożytnych. Mężczyźni opisywani przez autorów grecko-rzymskich, żydowskich i Pawła jako niepotrafiący nad sobą zapanować i pałający ku sobie żądzą (Rz 1,27), tracą męskość, której wyznacznikiem jest samoopanowanie i kierowanie się bardziej rozumem niż uczuciami. Argumentacja Pawła, która w Rz 1,18-32 w tak mocny sposób odwołuje się do kwestii honoru i wstydu, nie miałaby sensu, gdyby nie docierała do znakomitej części jego pogańskich odbiorców. Apostoł, konstruując swą mowę w Rz 1,18-32 na bardzo szerokiej podstawie, liczy na ich aprobatę i zrozumienie, i w istocie nie są to płonne oczekiwania. Jak argumentuje MacMullen, homoseksualny styl życia prowadziła i aprobowała jedynie wąska grupa należąca do miejskiej, bogatej, liberalnej elity, podczas gdy zasadnicza część społeczeństwa nie była mu przychylna.

Paweł znajduje także sprzymierzeńców dla swej myśli w autorach grecko-rzymskich i żydowskich, traktujących naturę i jej prawa jako część świata stworzonego, kierowanego boskim, rozumnym zamysłem. Ci, którzy próbują sprowadzić kwestie homoseksualne $\mathrm{u}$ apostoła do rangi normy kulturowej, lekceważą liczne teksty i autorów grecko-rzymskich i żydowskich, wiążących płciowość z naturą, a tę z kolei $\mathrm{z}$ boską wolą. Według Bożych praw, zapisanych w naturze i decydujących o naturze człowieka, rozróżnienie płciowe służy podtrzymywaniu rodzaju ludzkiego i przekazywaniu życia. Natura u Pawła daleka jest po prostu od świata naturalnego czy zwierzęcego, będąc przeniknięta zamysłem Stwórcy i stanowiąc przedmiot odkupieńczego działania Chrystusa (Rz 1,18-32).

W swojej argumentacji w rozdziale pierwszym Listu do Rzymian Paweł idzie za tradycją żydowską i za Pismami. Jego myśl wskazuje pokrewieństwo z Mdr 12-15 i zapisaną tam krytyką idolatrii, ale także nawiązuje do podobnej krytyki zapisanej w Księdze Powtórzonego Prawa (4,16-19) i do Kodeksu Świętości (Kpł 18,22 i 20,13). Najistotniejszym źródłem inspiracji jest jednak dla apostoła Księga Rodzaju (1,27-28), która zarówno pod względem słownictwa, jak i tematu stworzenia wykazuje istotne paralele z Rz 1,18-32. Pozwala to przyjąć, że Paweł odrzuca homoseksualizm przede wszystkim jako zacierający granice między mężczyzną a kobietą konieczne dla przekazywania życia, ale nie tylko. Mężczyzna i kobieta w myśli apostoła, podążającego tu także za Księgą Rodzaju, zostali sobie dani jako lekarstwo na ludzką samotność (Rdz 2,18), jako ci, którzy, uzupełniając się, pomagają sobie nawzajem w odkrywaniu własnej tożsamości i godności dzieci Bożych (Rdz 2,24; 1 Kor 11,3.7).

Argumenty z honoru i wstydu, prawa naturalnego i aluzje do Księgi Rodzaju wskazują, że Pawłowego pojmowania męskości i kobiecości nie da się oddzielić od moralności oraz rozróżnienia płciowego, jak chcieliby niektórzy współcześni komentatorzy. Na podobną operację nie pozwalają także przytoczeni autorzy starożytni, w których apostoł mógł znaleźć sprzymierzeńców dla swojej wizji seksualności. 
Paweł, obywatel świata grecko-rzymskiego i Żyd, żyje i tworzy korzystając z dorobku obu tych wymiarów kulturowych, które właściwie należy traktować jako jeden wymiar hellenistyczno-żydowski. Wnosi do niego równocześnie całą nowość objawienia, które dokonało się w Chrystusie, co także nie pozwala stępić jego przesłania na temat relacji homoseksualnych. Jak wszyscy grzesznicy, także homoseksualiści wezwani są do oddania się w ręce Chrystusa, który jako jedyny wybawia nas od nadchodzącego gniewu Bożego. Wezwanie to jest o tyle bardziej radykalne niż to, które znaleźć można w Starym Testamencie, że jest ostateczne i przypieczętowane przyjściem Mesjasza, jedynego Zbawcy ludzkości (Rz 3,22-24).

\section{Bibliografia}

von Arnim, H. - Radice, R., Stoici antichi, tutti i frammenti. Testo greco e latino a fronte. Introduzione, traduzione, note e apparati a cura di Roberto Radice (Il pensiero occidentale; Milano: Bompiani 2002).

Bailey, D.S., Homosexuality and the Western Christian Tradition (Hamden, CT: Archon Books 1975).

Ball, M.S., „Law Natural. Its Family of Metaphors and Its Theology”, Journal of Law and Religion $3 / 1(1985)$ 140-165.

Balz, H. - Schneider, G. (red.), Exegetical Dictionary of the New Testament (Grand Rapids, MI: Eerdmans 1990-1993) I-III (=EDNT)

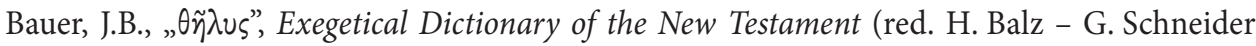
(Grand Rapids, MI: Eerdmans 1991) II, 147-148.

Biggar, N. - Black, R. (red.), The Revival of Natural Law. Philosophical and Theological Essays on the Finnis-Grisez School (Aldershot: Ashgate 1999).

Boswell, J., Christianity, Social Tolerance, and Homosexuality. Gay People in Western Europe from the Beginning of the Christian Era to the Fourteenth Century (Chicago, IL - London: University of Chicago Press 1980).

Boyarin, D., „Are There Any Jews in 'the History of Sexuality'?, Journal of the History of Sexuality 5 (1995) 333-355.

Brooten, B.J., Love Between Women. Early Christian Responses to Female Homoeroticism (The Chicago Series on Sexuality, History, and Society; Chicago, IL: University of Chicago Press 1996).

Bussey, P.J., „Natural Law. 'God's Law in Our Hearts”, Science and Christian Belief 32/1 (2020) 5-28.

Byrne, B., Romans (Sacra Pagina 6; Collegeville, MN: Liturgical Press 1996).

Cherry, M.J., Natural Law and the Possibility of a Global Ethics (Philosophical Studies in Contemporary Culture 11; Dordrecht: Kluwer Academic Publishers 2004).

Cohen, D., „Sexuality, Violence, and the Athenian Law of Hubris”, Greece and Rome 38 (1991) 171-188. 


\section{MARCIN KOWALSKI}

Cohen, D., Law, Sexuality and Society. The Enforcement of Morals in Classical Athens (Cambridge: Cambridge University Press 1991).

Collins, J.J., Jewish Wisdom in the Hellenistic Age (The Old Testament Library; Louisville, KY: Westminster John Knox 2011).

Covell, C., The Defence of Natural Law. A Study of the Ideas of Law and Justice in the Writings of Lon L. Fuller, Michael Oakeshot, F.A. Hayek, Ronald Dworkin and John Finnis, wyd. 3 (London: Palgrave Macmillan Limited 2016).

Cranfield, C.E.B., A Critical and Exegetical Commentary on the Epistle to the Romans. Introduction and Commentary on Romans I-VIII (International Critical Commentary; Edinburgh: Clark 2004).

Curran, C.E. - McCormick, R.A. (red.), Natural Law and Theology (Readings in Moral Theology 7; New York: Paulist Press 1991).

Davies, M., „New Testament Ethics and Ours: Homosexuality and Sexuality in Romans 1:26-27", Biblical Interpretation 3/3 (1995) 315-331.

DeYoung, J.B., „The Meaning of 'Nature' in Romans 1 and Its Implications for Biblical Proscriptions of Homosexual Behavior", Journal of the Evangelical Theological Society 31/4 (1988) 429-441.

Dover, K.J., Greek Homosexuality (Cambridge, MA: Harvard University Press 1989).

Dunn, J.D.G., Romans. I. 1 - 8 (Word Biblical Commentary 38A; Dallas, TX: Word 1988).

Esler, P.F., „The Sodom Tradition in Romans 1:18-32”, Biblical Theology Bulletin 34/1 (2004) 4-16.

Fitzmyer, J.A., Romans. A New Translation with Introduction and Commentary (Anchor Bible 33; New York: Doubleday 1993).

Fredrickson, D.E., „Natural and Unnatural Use in Romans 1:24-27. Paul and the Philosophic Critique of Eros", Homosexuality, Science, and the "Plain Sense" of Scripture (red. D.L. Balch) (Grand Rapids, MI: Eerdmans 2000) 197-222.

Furnish, V.P., The Moral Teaching of Paul (Nashville, TN: Abingdon 1979).

Gagnon, R.A.J., The Bible and Homosexual Practice (Nashville, TN: Abingdon 2002).

George, R.P. (red.), Natural Law Theory. Contemporary Essays (Oxford: Clarendon 1996).

Greenwood, D., „Saint Paul and Natural Law”, Biblical Theology Bulletin 1/3 (1971) 262-279.

Hallett, J.P., „Female Homoeroticism and the Denial of Roman Reality in Latin Literature”, Yale Journal of Criticism 3 (1989) 209-227.

Halperin, D.M., One Hundred Years of Homosexuality and Other Essays on Greek Love (New York: Routledge 1990).

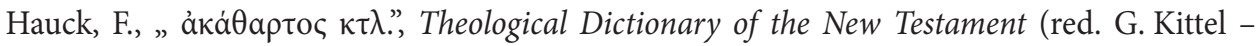
G. Friedrich - G.W. Bromiley) (Grand Rapids, MI - London: Eerdmans 1971) III, 426-431.

Hays, R.B., „Relations Natural and Unnatural. A Response to J Boswell's Exegesis of Rom 1”, Journal of Religious Ethics 14/1 (1986) 184-215.

Himbaza, I. - Schenker, A. - Edart, J.-B., The Bible on the Question of Homosexuality (Washington, D.C.: Catholic University of America Press 2012).

Hittinger, R., „The Recovery of Natural Law and the 'Common Morality”, This World 18 (1987) 62-74.

Horsley, A., „The Law of Nature in Philo and Cicero”, Harvard Theological Review 71 (1978) $35-59$. 
Hubbard, T.K., Homosexuality in Greece and Rome. A sourcebook of basic documents (Joan Palevsky Imprint in Classical Literature; Berkeley, CA: University of California Press 2003).

Hyldahl, N., „Reminiscence of the Old Testament at Romans 1:23”, New Testament Studies 2/4 (1956) 285-288.

Inwood, B., Ethics and Human Action in Early Stoicism (Oxford: Clarendon - New York: Oxford University Press 1985).

Jewett, R. - Kotansky, R.D., Romans. A Commentary on the Book of Romans (Hermeneia; Minneapolis, MN: Fortress 2007).

Johnson, A.F., „Is There a Biblical Warrant for Natural-Law Theories”, Journal of the Evangelical Theological Society 25/2 (1982) 185-199.

Kalin, E.R., „Romans 1:26-27 and Homosexuality”, Currents in Theology and Mission 30/6 (2003) 423-432.

Kittel, G. - Friedrich, G. - Bromiley, G.W. (red.), Theological Dictionary of the New Testament (Grand Rapids, MI - London: Eerdmans 1964-1976) I-X [electronic edition 2000] $(=T D N T)$.

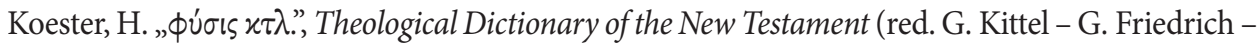
G.W. Bromiley) (Grand Rapids, MI - London: Eerdmans 1971) IX, 250-277.

Kowalski, M., „Apokaliptyczny gniew Boga i jego miejsce w Ewangelii Pawła (Rz 1,18-32)”, Verbum Vitae 33 (2018) 203-249.

Kowalski, M., „Między darem Bożym a konstruktem społecznym. Wczesnochrześcijańskie rozumienie płciowości na podstawie 1 Kor 11,2-16", Biblica et Patristica Thorunensia 13/1 (2020) 59-104.

Krawczyk, M.A., „Michael Riffaterre's 'Interpretant' Reinterpreted. An Approach for the Hypertextual Reading of Wisdom and Romans", BibAn 10/2 (2020) 261-277.

Linebaugh, J.A., „Announcing the Human. Rethinking the Relationship Between Wisdom of Solomon 13-15 and Romans 1.18-2.11", New Testament Studies 57/2 (2011) 214-237.

Longenecker, R.N., The Epistle to the Romans. A Commentary on the Greek Text (New International Greek Testament Commentary; Grand Rapids, MI: Eerdmans 2016).

Lucas, A., „Distinct Portraits and Parallel Development of the Knowledge of God in Romans 1:18-32 and Wisdom of Solomon 13-15", Christian Body, Christian Self. Concepts of Early Christian Personhood (red. C.K. Rothschild - T.W. Thompson) (Wissenschaftliche Untersuchungen zum Neuen Testament284; Tübingen: Mohr Siebeck 2011) 61-82.

MacMullen, R., „Roman Attitudes to Greek Love”, Historia 31/4 (1982) 484-502.

MacNeill, J.J., The Church and the Homosexual, wyd. 4 (Boston, MA: Beacon Press 1993).

Martin, D.B., „Heterosexism and the Interpretation of Romans 1:18-32”, Biblical Interpretation 3/3 (1995) 332-355.

McKenzie, J.L., „Natural Law in the New Testament”, Biblical Research 9 (1964) 3-13.

Michaelis, W., „तá日oc”, Theological Dictionary of the New Testament (red. G. Kittel - G. Friedrich G.W. Bromiley) (Grand Rapids, MI - London: Eerdmans 1971) V, 926-930.

Miller, J.E., „The Practices of Romans 1:26: Homosexual or Heterosexual?”, Novum Testamentum 37/1 (1995) 1-11.

Moo, D.J., The Epistle to the Romans (New International Commentary on the New Testament; Grand Rapids, MI: Eerdmans 1996). 


\section{MARCIN KOWALSKI}

Mueller, E., Homosexuality, Scripture, and the Church (Silver Spring, MD: Biblical Research Institute 2010).

Osiek, C. - Pouya, J., „Constructions of Gender in the Roman Imperial World”, Understanding the Social World of the New Testament (red. D. Neufeld - R.E. DeMaris) (London - New York: Routledge 2010) 44-56.

Osiek, C.A. - Balch, D.L., Families in the New Testament World. Households and House Churches (Louisville, KY: Westminster John Knox 1997).

Paul, E.F. - Miller, F.D. - Paul, J. (red.), Natural Law and Modern Moral Philosophy (Cambridge: Cambridge University Press 2001).

Reese, J.M., Hellenistic Influence on the Book of Wisdom and Its Consequences (Analecta Biblica 41; Rome: Pontifical Biblical Institute 1971).

Remus, H.E., „Authority, Consent, Law. Nomos, Physis, and the Striving for a 'Given”, Studies in Religion 13/1 (1984) 5-18.

Richlin, A., „Not Before Homosexuality. The Materiality of the Cinaedus and the Roman Law against Love between Men", Journal of the History of Sexuality 3 (1993) 523-573.

Rogers, J., Jesus, the Bible, and Homosexuality. Explode the Myths, Heal the Church (Louisville, KY: Westminster John Knox 2009).

Sanday, W. - Headlam, A.C., A Critical and Exegetical Commentary on the Epistle to the Romans (International Critical Commentary on the Holy Scriptures of the Old and New Testaments; New York: Scribner 1897).

Schreiner, T.R., Romans (Baker Exegetical Commentary on the New Testament 6; Grand Rapids, MI: Baker 1998).

Scroggs, R., The New Testament and Homosexuality. Contextual Background for Contemporary Debate (Philadelphia, PA: Fortress 1983).

Skinner, B.G., „New Testament Ethics and Natural Law”, Church Quarterly Review 165 (1964) 8-17.

Smith, M.D., „Ancient Bisexuality and the Interpretation of Romans 1:26-27”, Journal of the American Academy of Religion 64/2 (1996) 223-256.

Stegemann, W., „Paul and the Sexual Mentality of His World”, Biblical Theology Bulletin 23/4 (1993) 161-166.

Striker, G., „Origins of the Concept of Natural Law”, Proceedings of the Boston Area Colloquium in Ancient Philosophy 2 (1987) 79-94.

Stuhlmacher, P., Paul's Letter to the Romans. A Commentary (Louisville, KY: Westminster John Knox 1994).

Ward, R.B., „Why Unnatural? The Tradition behind Romans 1:26-27”, The Harvard Theological Review 90/3 (1997) 263-284.

Weinreb, L.L., Natural Law and Justice (Cambridge, MA: Harvard University Press 1987).

Wilckens, U., Der Brief an die Römer (Evangelisch-katholischer Kommentar zum Neuen Testament; Neukirchen-Vluyn: Neukirchener Verlag - Zurich: Benziger 1978-1981) I-III.

Williams, C.A., Roman Homosexuality, wyd. 2 (New York - Oxford: Oxford University Press 2010).

Wink, W., „Homosexuality and the Bible”, Homosexuality and Christian Faith. Questions of Conscience for the Churches (red. W. Wink) (Minneapolis, MN: Fortress 1999) 33-49. 
Winkler, J.J., The Constraints of Desire. The Anthropology of Sex and Gender in Ancient Greece (New York: Routledge 1990).

Winston, D., The Wisdom of Solomon. A New Translation with Introduction and Commentary (Anchor Bible 43; New Haven, CT - London: Yale University Press 2008).

Witherington III, B. - Hyatt, D., Paul's Letter to the Romans. A Socio-Rhetorical Commentary (Grand Rapids, MI: Eerdmans 2004). 
